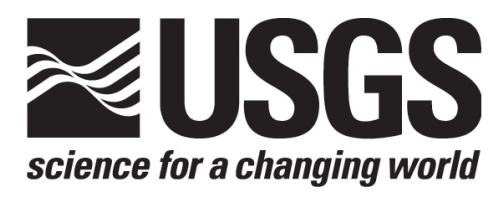

\title{
Analytic Resource Assessment Method for Continuous (Unconventional) Oil and Gas Accumulations-The "ACCESS" Method
}

By Robert A. Crovelli, revised by Ronald R. Charpentier, 2012

Open-File Report 2012-1146 


\title{
U.S. Department of the Interior \\ KEN SALAZAR, Secretary
}

\author{
U.S. Geological Survey \\ Marcia K. McNutt, Director
}

U.S. Geological Survey, Reston, Virginia: 2012

For more information on the USGS-the Federal source for science about the Earth,

its natural and living resources, natural hazards, and the environment-visit

http://www.usgs.gov or call 1-888-ASK-USGS

For an overview of USGS information products, including maps, imagery, and publications,

visit $h$ ttp://www.usgs.gov/pubprod

To order this and other USGS information products, visit $h$ ttp://store.usgs.gov

Suggested citation:

Crovelli, R.A., 2012, Analytical resources assessment method for continuous (unconventional) oil and gas accumulations-The "ACCESS Method": U.S. Geological Survey Open-File Report 2012-1146, 32 p. [Revised by Charpentier, R.R.]

Any use of trade, product, or firm names is for descriptive purposes only and does not imply endorsement by the U.S. Government.

Although this report is in the public domain, permission must be secured from the individual copyright owners to reproduce any copyrighted material contained within this report. 


\section{Contents}

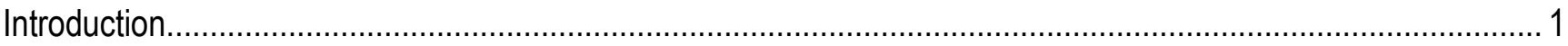

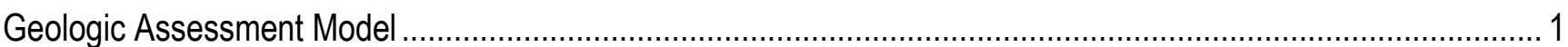

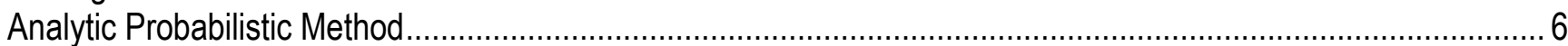

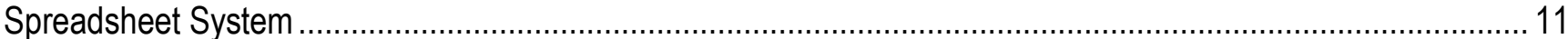

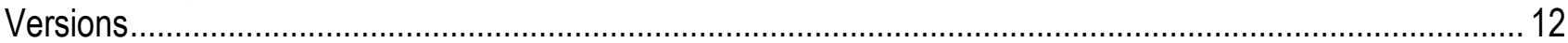

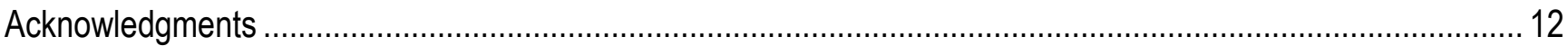

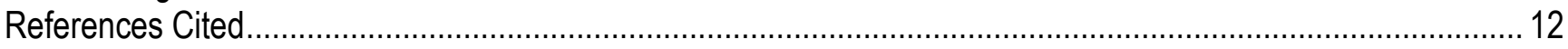

\section{Figures}

1. Example of basic input data form for FORSPAN assessment model. (Assessment-unit type: oil).....

2. Example of basic input data form for FORSPAN assessment model. (Assessment-unit type: gas)

3. Simplified flow chart of the analytic probabilistic method for resource assessment of continuous (unconventional) oil and gas accumulations-the ACCESS method

4. Flow chart of calculations for determining the number of potential cells

\section{Table}

1. Spreadsheet ACCESS panel numbers and contents 


\title{
Analytic Resource Assessment Method for Continuous (Unconventional) Oil and Gas Accumulations-The "ACCESS" Method
}

\author{
By Robert A. Crovelli, ${ }^{1}$ revised by Ronald R. Charpentier, ${ }^{1} 2012$
}

\section{Introduction}

The U.S. Geological Survey (USGS) periodically assesses petroleum resources of areas within the United States and the world. The purpose of this report is to explain the development of an analytic probabilistic method and spreadsheet software system called Analytic Cell-Based Continuous Energy Spreadsheet System (ACCESS). The ACCESS method is based upon mathematical equations derived from probability theory. The ACCESS spreadsheet can be used to calculate estimates of the undeveloped oil, gas, and NGL (natural gas liquids) resources in a continuous-type assessment unit. An assessment unit is a mappable volume of rock in a total petroleum system. In this report, the geologic assessment model is defined first, the analytic probabilistic method is described second, and the spreadsheet ACCESS is described third. In this revised version of Open-File Report 00-044, the text has been updated to reflect modifications that were made to the ACCESS program. Two versions of the program are added as appendixes.

\section{Geologic Assessment Model}

The geologic assessment model is called the FORSPAN model and is described in Schmoker (1999). The geologic assessment model for an assessment unit consists of the following components (see figs. 1 and 2 for additional descriptions):

A. A set of four assessment-unit probabilities:
1. Charge
2. Rocks
3. Timing
4. Access

B. A set of nine random variables for an oil assessment unit or a similar set for a gas assessment unit:

1. Total assessment-unit area

2. Area per cell

3. Percentage of total assessment-unit area that is untested

${ }^{1}$ U.S. Geological Survey, MS 939, Box 25046, Denver Federal Center, Denver, Colorado 80225 
4. Percentage of untested assessment-unit area that has potential for additions to reserves

5. Total recovery per cell

6. Ratio of coproduct A

7. Ratio of coproduct B

8. Percent allocation to parcel (or land entity)

9. Percent allocation to offshore portion of parcel

(The assessment-unit area, untested percentage of assessment-unit area, percentage of untested assessment-unit area with potential, and area per cell are used to determine the number of potential cells, as explained later.)

C. A set of three descriptive parameters for each of the nine given random variables:

1. Minimum (F100)

2. Median (F50) or mode (most likely), depending on the version of the program (see p. 13)

3. Maximum (FO)

Examples of the basic input data form for the FORSPAN model are given in figures 1 and 2. 


\begin{tabular}{|c|c|c|c|c|c|c|c|c|}
\hline \multicolumn{9}{|c|}{ FORSPAN ASSESSMENT MODEL FOR CONTINUOUS } \\
\hline \multicolumn{9}{|c|}{ ACCUMULATIONS--BASIC INPUT DATA FORM (NOGA, Version 9, 2-10-03) } \\
\hline & & & & & & & & \\
\hline \multicolumn{9}{|c|}{ IDENTIFICATION INFORMATION } \\
\hline \multicolumn{2}{|c|}{ Assessment Geologist: } & \multicolumn{3}{|c|}{ R.F. Dubiel and J.K. Pitman } & & & \multirow{2}{*}{$\begin{array}{l}\text { Date: } \\
\text { Number: }\end{array}$} & \multirow{2}{*}{$\frac{10 / 27 / 2010}{5}$} \\
\hline \multicolumn{2}{|c|}{ Region: } & \multicolumn{2}{|c|}{ North America } & & & & & \\
\hline \multicolumn{2}{|c|}{ Province: } & Gulf Coast M & Mesozoic & & & & Number: & 5049 \\
\hline \multicolumn{2}{|c|}{ Total Petroleum System: } & \multicolumn{4}{|c|}{ Upper Jurassic-Cretaceous-Tertiary Composite } & & \multirow{3}{*}{$\begin{array}{l}\text { Number: } \\
\text { Number: }\end{array}$} & 504901 \\
\hline \multicolumn{2}{|c|}{ Assessment Unit: } & \multicolumn{2}{|c|}{ Eagle Ford Shale Oil } & & & & & 50490170 \\
\hline \multicolumn{2}{|c|}{ Based on Data as of: } & \multicolumn{2}{|l|}{ IHS 2010} & & & & & \\
\hline & & & & & & & & \\
\hline & tes from Assessor: & & & & & & & \\
\hline & & & & & & & & \\
\hline & & & & & & & & \\
\hline & & & & & & & & \\
\hline & & CHA & RACTERISTI & ICS OF ASSE & ESSMENT UN & NIT & & \\
\hline & & & & & & & & \\
\hline & sessment-unit type: $O$ & il $(<20,000 \mathrm{cf}$ & $\mathrm{fg} / \mathrm{bo})$ or Gas & $(\geq 20,000 \mathrm{cfg}$ & y/bo), incl. dis & c. \& pot. addi & itions & Oil \\
\hline & nat is the minimum tot & tal recovery & per cell? & 0.002 & (mmbo for oil & A.U.; bcfg fo & or gas A.U.) & \\
\hline & mber of tested cells: & 85 & & & & & & \\
\hline & mber of tested cells with & $\overline{\mathrm{h} \text { total recover }}$ & ry per cell $\geq m$ & minimum: & 64 & & & \\
\hline & tablished (discovered cel & $\mathrm{x}$ & Hypothetical ( & (no cells): & & & & \\
\hline & dian total recovery per $\mathrm{c}$ & $\overline{\text { cell (for cells } \geq}$ & $\geq \min .):(\mathrm{mmb}$ & bo for oil A.U. & $\overline{\text { bcfg for gas }}$ & A.U.) & & \\
\hline & & 1st 3rd dis & covered & 0.017 & 2nd 3rd & 0.039 & 3rd 3rd & 0.011 \\
\hline & sessment-Unit Probabi & & & & & & & \\
\hline & $\begin{array}{l}\text { sessment-Unit Probabi } \\
\text { Attribute }\end{array}$ & ilities: & & Prob & Jability of occl & urrence $(0-1.0$ & & \\
\hline & CHARGE: Adequate pet & troleum charg & for an untes & sted cell with & total recovery & $\geq$ minimum & & 1.0 \\
\hline & ROCKS: Adequate reser & rvoirs, traps, & seals for an $u$ & untested cell v & with total reco & very $\geq$ minim & um. & 1.0 \\
\hline & TIMING: Favorable geolc & ogic timing for & r an untested & cell with tota & al recovery $\geq n$ & ninimum. & & 1.0 \\
\hline & & & & & & & & \\
\hline & sessment-Unit GEOLOC & GIC Probabil & lity (Product $\mathrm{C}$ & of 1,2 , and 3 & & & & 1.0 \\
\hline & & & & & & & & \\
\hline & & & & & & & & \\
\hline & & & & & & & & \\
\hline & & & & & & & & \\
\hline & & & & & & & & \\
\hline & NO. OF U & JNTESTED C & ELLS WITH & POTENTIAL & FOR ADDITIC & ONS TO RES & SERVES & \\
\hline & & & & & & & & \\
\hline 1. & Total assessment-unit & area (acres): & (uncertainty & of a fixed valu & ue) & & & \\
\hline & & & & & & & & \\
\hline & calculated mean & $16,474,000$ & minimum & $14,827,000$ & mode & $16,474,000$ & maximum & $18,121,000$ \\
\hline 2. & Area per cell of unteste & ed cells having & g potential for & r additions to & reserves (acre & es): (values a & are inherently & variable) \\
\hline & & & & & & & & \\
\hline & calculated mean & 176 & minimum & 80 & mode & 128 & maximum & 320 \\
\hline & & & & & & & & \\
\hline & uncertainty of mean: & minimum & 125 & maximum & 225 & & & \\
\hline & & & & & & & & \\
\hline 3. & Percentage of total ass & sessment-unit & $\mathrm{t}$ area that is $\mathrm{c}$ & untested (\%): & : (uncertainty & of a fixed val & lue) & \\
\hline & & & & & & & & \\
\hline & calculated mean & 100 & minimum & 100 & mode & 100 & maximum & 100 \\
\hline & & & & & & & & \\
\hline & & & & & & & & \\
\hline
\end{tabular}

Figure 1. Example of basic input data form for FORSPAN assessment model. (Assessment-unit type: oil) 


\section{NO. OF UNTESTED CELLS WITH POTENTIAL FOR ADDITIONS TO RESERVES}

(Continued)

4. Percentage of untested assessment-unit area that has potential for additions to reserves (\%): ( a necessary criterion is that total recovery per cell $\geq$ minimum; uncertainty of a fixed value)

calculated mean

17

minimum

0.5

mode

9

maximum

40

Geologic evidence for estimates:

Good TOC and thermal maturity throughout AU.

Generation and migration north into Conv clastic AU and upsection into Austin Chalk.

Best area in SW where brittle marl and siltstone interbeds yield fractures.

TOTAL RECOVERY PER CELL

Total recovery per cell for untested cells having potential for additions to reserves:

(values are inherently variable; mmbo for oil A.U.; bcfg for gas A.U.)

calculated mean $\quad 0.055$

minimum

0.002

median

0.03

maximum

1

AVERAGE COPRODUCT RATIOS FOR UNTESTED CELLS, TO ASSESS COPRODUCTS

(uncertainty of fixed but unknown values)

Oil assessment unit:

Gas/oil ratio (cfg/bo)

$\mathrm{NGL} / \mathrm{gas}$ ratio (bngl/mmcfg)

minimum

1000

mode

2000

maximum

10

20

30

Gas assessment unit:

Liquids/gas ratio (bliq/mmcfg)

Figure 1. Example of basic input data form for FORSPAN assessment model. (Assessment-unit type: oil).-Continued 


\begin{tabular}{|c|c|c|c|c|c|c|c|c|}
\hline & & FORSPA & AN ASSESSI & MENT MODE & EL FOR CON & JTINUOUS & & \\
\hline & ACCUM & IULATIONS- & --BASIC INPL & UT DATA FC & ORM (NOGA, & , Version 9, & 2-10-03) & \\
\hline & & & & & & & & \\
\hline & & & IDENTIFIC & SATION INFC & ORMATION & & & \\
\hline As: & sessment Geologist: & D.W. House & eknecht & & & & Date: & 26-Jan-10 \\
\hline $\operatorname{Re}$ & gion: & North Ameri & & & & & Number: & 5 \\
\hline Pro & vince: & Arkoma Bas & & & & & Number: & 5062 \\
\hline Tot & al Petroleum System: & Woodford-C & Chattanooga & & & & Number: & 506202 \\
\hline As: & sessment Unit: & Woodford S & hale Gas & & & & Number: & 50620261 \\
\hline & sed on Data as of: & IHS (2009) & & & & & & \\
\hline & & & & & & & & \\
\hline Not & es from Assessor: & & & & & & & \\
\hline & & & & & & & & \\
\hline & & & & & & & & \\
\hline & & & & & & & & \\
\hline & & CHA & ARACTERIST & TICS OF ASS & SESSMENT I & UNIT & & \\
\hline & & & & & & & & \\
\hline As: & sessment-unit type: 0 & il $(<20,000 c$ & $\mathrm{cfg} / \mathrm{bo}$ ) or $\mathbf{G a}$ & as $(\geq 20,000 \mathrm{c}$ & cfg/bo), incl. c & disc. \& pot. & additions & Gas \\
\hline Wh & lat is the minimum to & tal recovery & y per cell? & 0.02 & (mmbo for oi & il A.U.; bcfg & for gas A.U.) & \\
\hline Nul & nber of tested cells: & 985 & & & & & & \\
\hline Nul & nber of tested cells witr & $\mathrm{h}$ total recove & ery per cell $\geq$ & minimum: & 926 & & & \\
\hline Est & ablished (discovered cel & $\mathrm{X}$ & Hypothetical ( & (no cells): & & & & \\
\hline $\mathrm{Me}$ & dian total recovery per c & cell (for cells & $\geq \min .):(\mathrm{mm}$ & nbo for oil A. & U.; bcfg for $g$ & jas A.U.) & & \\
\hline & & 1st 3rd dis & iscovered & 1 & 2nd 3rd & 0.75 & 3rd 3rd & 0.5 \\
\hline As: & sessment-Unit Probab & ilities: & & & & & & \\
\hline & Attribute & & & Pro & obability of oc & currence $(0$ & $-1.0)$ & \\
\hline 1. & CHARGE: Adequate pet & troleum chars & ge for an unte & ested cell wit & ith total recove & ery $\geq \operatorname{minim}$ & um. & 1.0 \\
\hline 2. 1 & ROCKS: Adequate rese & rvoirs, traps, & seals for an & untested cel & ll with total re & ecovery $\geq \mathrm{mi}$ & inimum. & 1.0 \\
\hline 3. 7 & IIMING: Favorable geol & logic timing fo & or an untestec & ed cell with to & otal recovery & $\geq$ minimum. & & 1.0 \\
\hline As & sessment-Unit GEOLO & GIC Probabi & ility (Product & t of 1,2 , and & 3): & & & 1.0 \\
\hline & & & & & & & & \\
\hline & & & & & & & & \\
\hline & & & & & & & & \\
\hline & & & & & & & & \\
\hline & & & & & & & & \\
\hline & NO. OF U & JNTESTED C & ;ELLS WITH & I POTENTIAL & L FOR ADDIT & TIONS TO F & RESERVES & \\
\hline & & & & & & & & \\
\hline 1. & Total assessment-unit & area (acres): & : (uncertainty & ty of a fixed $v$ & value) & & & \\
\hline & & & & & & & & \\
\hline & calculated mean & $6,100,000$ & minimum & $5,800,000$ & mode & $6,100,000$ & maximum & $6,400,000$ \\
\hline 2. & Area per cell of unteste & ed cells havin & ng potential fo & or additions $t$ & to reserves (a & acres): (valu & es are inherer & ntly variable) \\
\hline & & & & & & & & \\
\hline & calculated mean & 167 & minimum & 60 & mode & 120 & maximum & 320 \\
\hline & & & & & & & & \\
\hline & uncertainty of mean: & minimum & 100 & maximum & 240 & & & \\
\hline 3. & Percentage of total ass & sessment-un & it area that is & s untested (\% & $\%$ ): (uncertair & nty of a fixec & d value) & \\
\hline & & & & & & & & \\
\hline & calculated mean & 97 & minimum & 96 & mode & 97 & maximum & 98 \\
\hline & & & & & & & & \\
\hline & & & & & & & & \\
\hline
\end{tabular}

Figure 2. Example of basic input data form for FORSPAN assessment model. (Assessment-unit type: gas) 


\begin{tabular}{|c|c|c|c|c|c|c|c|c|}
\hline & & & \multirow{2}{*}{\multicolumn{3}{|c|}{ Assessment Unit (name, no.) }} & & & \\
\hline & & & & & & & & \\
\hline & & & \multicolumn{3}{|c|}{ Woodford Shale Gas, 50620261} & & & \\
\hline & & & & & & & & \\
\hline & & & & & & & & \\
\hline & & & & & & & & \\
\hline \multicolumn{9}{|c|}{ NO. OF UNTESTED CELLS WITH POTENTIAL FOR ADDITIONS TO RESERVES } \\
\hline \multicolumn{9}{|c|}{ (Continued) } \\
\hline & & & & & & & & \\
\hline 4. & \multirow{2}{*}{\multicolumn{7}{|c|}{$\begin{array}{l}\text { Percentage of untested assessment-unit area that has potential for additions to reserves (\%): } \\
\text { ( a necessary criterion is that total recovery per cell } \geq \text { minimum; uncertainty of a fixed value) }\end{array}$}} & \\
\hline & & & & & & & & \\
\hline & & & & & & & & \\
\hline & calculated mean & 38 & minimum & 10 & mode & 35 & maximum & 70 \\
\hline & & & & & & & & \\
\hline & \multicolumn{2}{|c|}{ Geologic evidence for estimates } & & & & & & \\
\hline & \multicolumn{8}{|c|}{ Min scenario: lower productivity in (1) areas of low gross \& net GR, (2) areas of high thermal maturity $\left(>3.0-3.5^{\circ}\right.$} \\
\hline & \multicolumn{8}{|c|}{ along southern margin of $\mathrm{AU}$, and (3) area of near-exposure along southwestern margin of Ozark uplift. } \\
\hline & \multicolumn{5}{|c|}{ Max scenario: moderate to good productivity in areas (1), (2), and (3). } & & & \\
\hline & & & & & & & & \\
\hline & & & & & & & & \\
\hline & & & & & & & & \\
\hline & & & & & & & & \\
\hline \multicolumn{9}{|c|}{ TOTAL RECOVERY PER CELL } \\
\hline & & & & & & & & \\
\hline \multicolumn{7}{|c|}{ Total recovery per cell for untested cells having potential for additions to reserves: } & & \\
\hline \multicolumn{6}{|c|}{ (values are inherently variable; mmbo for oil A.U.; bcfg for gas A.U.) } & & & \\
\hline & & & & & & & & \\
\hline & calculated mean & 0.78 & minimum & 0.02 & median & 0.5 & maximum & 10 \\
\hline & & & & & & & & \\
\hline & & & & & & & & \\
\hline \multicolumn{9}{|c|}{ AVERAGE COPRODUCT RATIOS FOR UNTESTED CELLS, TO ASSESS COPRODUCTS } \\
\hline \multicolumn{9}{|c|}{ (uncertainty of fixed but unknown values) } \\
\hline & assessment unit: & & & minimum & & mode & & maximum \\
\hline \multicolumn{2}{|r|}{ Gas/oil ratio (cfg/bo) } & & & & & & & \\
\hline \multicolumn{3}{|c|}{ NGL/gas ratio (bngl/mmcfg) } & & & & & & \\
\hline & & & & & & & & \\
\hline \multicolumn{9}{|c|}{ Gas assessment unit: } \\
\hline \multicolumn{3}{|c|}{ Liquids/gas ratio (bliq/mmcfg) } & & 0 & & 0 & & 40 \\
\hline & & & & & & & & \\
\hline & & & & & & & & \\
\hline
\end{tabular}

Figure 2. Example of basic input data form for FORSPAN assessment model. (Assessment-unit type: gas)-Continued

\section{Analytic Probabilistic Method}

The geologic assessment model FORSPAN is a description of a complex probability problem that needs to be solved in order to produce the estimates of the undeveloped petroleum resources (potential additions to reserves). The method derived herein, called ACCESS, is a system that solves the problem. That is, the model FORSPAN poses the problem, and the method ACCESS offers a solution. Simply stated, ACCESS is a solution of FORSPAN.

The nine given random variables (below) are assigned probability distributions as probability models that are based on the descriptive parameters (F100, F50 or mode, and F0). That is, each given random variable is assigned a probability distribution with the specified descriptive parameters: minimum, median or mode, and maximum. It is important to realize that the ACCESS method does not 
depend upon the specific assignment of probability distributions; this means many assignments could be accommodated by a modification of ACCESS. The assignment is an operational decision. The following probability distributions were assigned to the set of nine given random variables for an oil assessment unit or for a gas assessment unit:

1. Assessment-unit area: Triangular distribution

2. Area per cell: Triangular distribution

3. Percentage of total assessment-unit area that is untested: Triangular distribution

4. Percentage of untested assessment-unit area that has potential for additions to reserves: Triangular distribution

5. Total recovery per cell: Truncated shifted lognormal distribution

6. Ratio of coproduct A: Triangular distribution

7. Ratio of coproduct B: Triangular distribution

8. Percent allocation to parcel (or land entity): Triangular distribution

9. Percent allocation to offshore: Triangular distribution

The mathematical equations for the triangular distribution are derived from probability theory in Crovelli (1999). The basic probability theory of the triangular distribution is given in Law and Kelton (1991). The probability theory of the lognormal distribution is given in Aitchison and Brown (1957).

A probabilistic method must be derived that combines given random variables of the geologic assessment model (FORSPAN) to determine parameters (especially the mean, standard deviation, F95 fractile, and F5 fractile) of new random variables of interest - these new random variables are functions of the given random variables. The new random variables of interest are the following measures of undeveloped petroleum resources (potential additions to reserves):

1. Oil in oil assessment unit

2. Gas in oil assessment unit

3. NGL in oil assessment unit

4. Gas in gas assessment unit

5. NGL in gas assessment unit

6. Oil in gas assessment unit

A probabilistic method is required to compute the estimates of a probability distribution in the form of parameters (especially the mean for a point estimate and fractiles F95 and F5 for an interval estimate). An analytic probabilistic method is a probabilistic method that uses mathematical equations from probability theory to obtain the estimates of the undeveloped petroleum resources in an assessment unit. The ACCESS method is an analytic probabilistic method that was developed by deriving the necessary mathematical equations based upon conditional probability theory and laws of expectation and variance. Three features of ACCESS are the following:

1. ACCESS relates the parameters with mathematical equations.

2. ACCESS computes the means, standard deviations, minimums, and maximums exactly.

3. ACCESS computes the estimates instantaneously.

For example, in the case of gas in a gas assessment unit, the following relationships are developed for the random variables:

$N$ : Number of potential cells

$X$ : Total recovery per cell (billion cubic feet of gas) 
$Y$ : Gas in gas assessment unit (billion cubic feet of gas)

$$
Y=\sum_{i=1}^{N} X_{i}
$$

The random variable $Y$ is equal to the sum of a random number of random variables (total recoveries per cell). The mean and standard deviation of $Y$ can be derived from the theory of conditional probability and conditional expectation (Ross, 1993). Parameters of particular interest for gas in a gas assessment unit are the mean, standard deviation, minimum, and maximum:

$$
\begin{aligned}
& \mu_{Y}=\mu_{N} \mu_{X} \\
& \sigma_{Y}=\sqrt{\mu_{N} \sigma_{X}^{2}+\mu_{X}^{2} \sigma_{N}^{2}} \\
& \operatorname{Min}(\mathrm{Y})=\operatorname{Min}(\mathrm{N}) \operatorname{Min}(\mathrm{X}) \\
& \operatorname{Max}(\mathrm{Y})=\operatorname{Max}(\mathrm{N}) \operatorname{Max}(\mathrm{X})
\end{aligned}
$$

Many of the mathematical equations for parameters of the new random variables of interest in the ACCESS method are derived using conditional probability theory in Crovelli (1992). A simplified flow chart of the analytic probabilistic method for resource assessment of continuous (unconventional) oil and gas accumulations (the ACCESS method) is displayed in figure 3. The number of potential cells and the total recovery per cell are combined probabilistically to obtain the undeveloped petroleum resources (potential additions to reserves) in an assessment unit.

How the assessment-unit area, untested percentage of the assessment-unit area, percentage of the untested assessment-unit area with potential, and area per cell are used to determine the number of potential cells will now be explained. The assessment-unit area, untested percentage of the assessment-unit area, and percentage of the untested assessment-unit area with potential are multiplied probabilistically to obtain the potential area of the assessment unit. Then the potential area of the assessment unit and area per cell are combined to generate the number of potential cells. This sequence of calculations for the number of potential cells is described in the flow chart of figure 4 . 
Number of potential cells

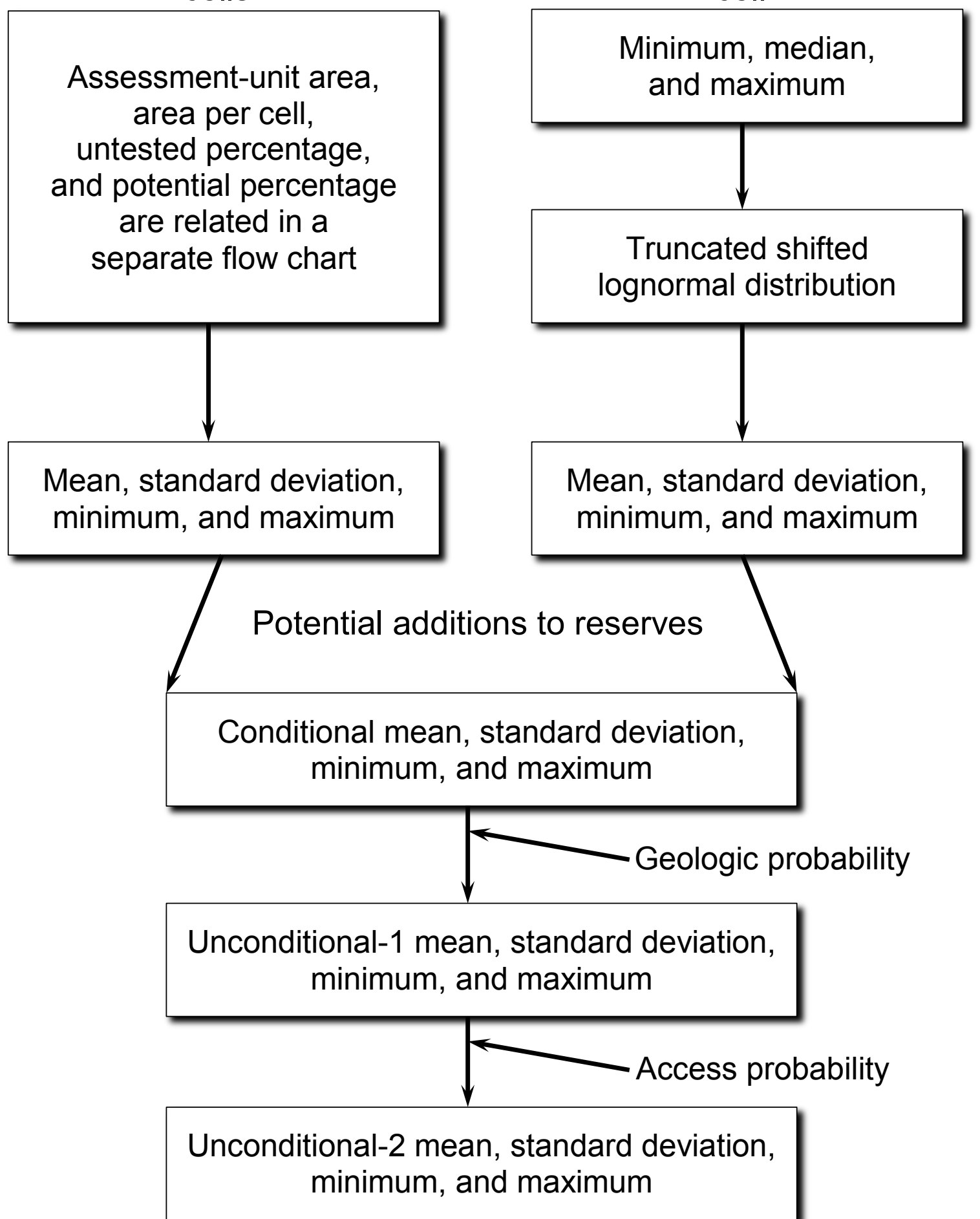

Figure 3. Simplified flow chart of the analytic probabilistic method for resource assessment of continuous (unconventional) oil and gas accumulations-the ACCESS method. 


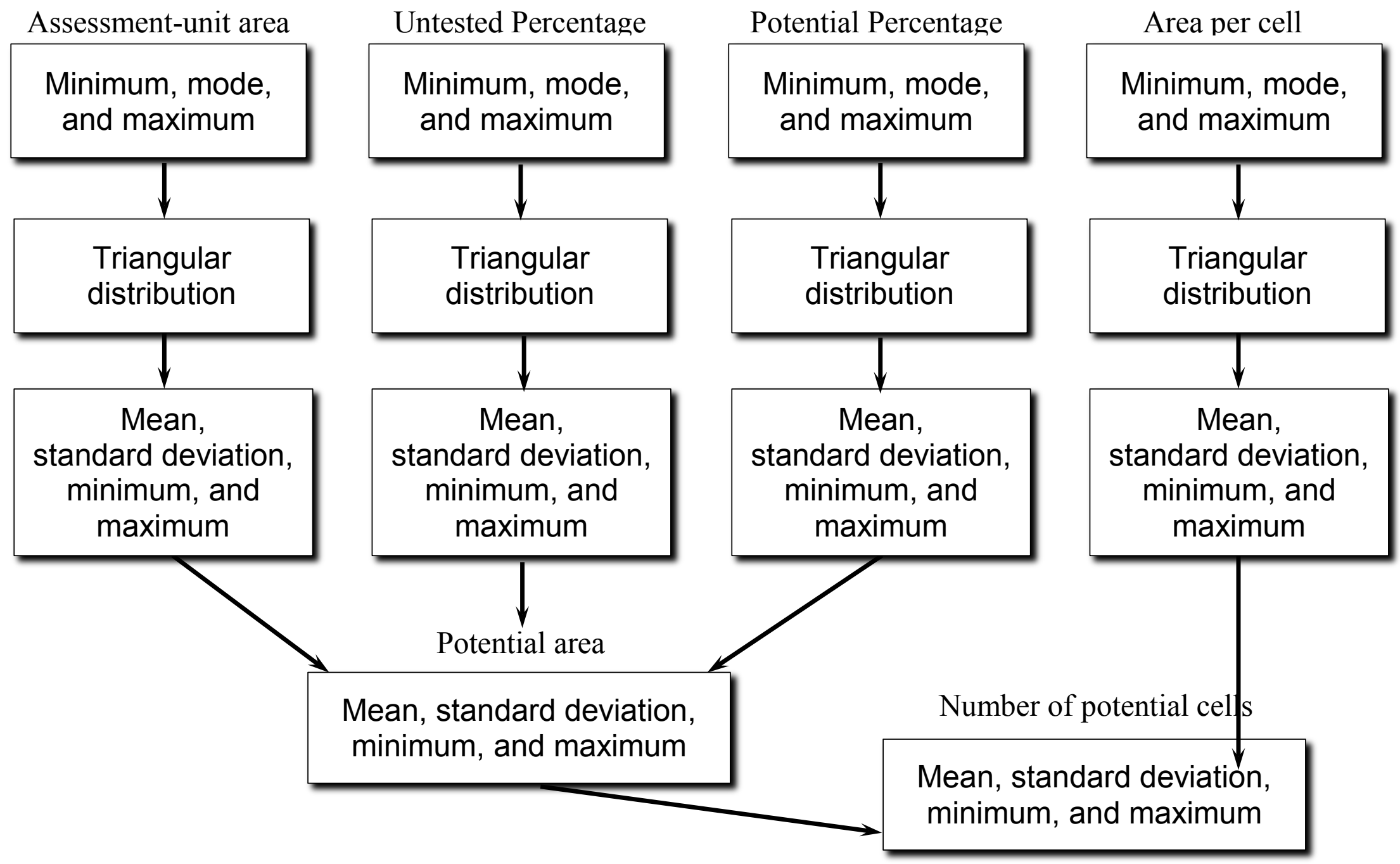

Figure 4. Flow chart of calculations for determining the number of potential cells. 


\section{Spreadsheet System}

Given the geologic assessment model (the FORSPAN model, figs. 1 and 2), the analytic probabilistic method is used to create a spreadsheet probability system. The analytic probabilistic method of the previous section is incorporated into the ACCESS software system. ACCESS consists of a series of 54 panels in the spreadsheet. A panel is a set of approximately 11 columns of related calculations. Because the total number of columns in ACCESS is 657, it was necessary to construct ACCESS as a workbook with four worksheets called Cond (Conditional), Unc1 (Unconditional-1_, Unc2 (Unconditional-2), and Numb. Cond comprises Panels 1-22, Unc1 contains Panels 23-34, Unc2 contains Panels 35-46, and Numb contains Panels 47-54. Worksheet Cond is linked to the worksheet Numb. Worksheets Unc1 and Unc2 are linked to the worksheet Cond. The topics contained in the worksheets Cond, Unc1, Unc2, and Numb are the following:

1. Worksheet Cond: Input data (Panels 1-4), probability distribution calculations (Panels 5-10), and conditional (unrisked) resource estimates (Panels 11-22).

2. Worksheet Unc1: Unconditional-1 resource estimates, risked using the geologic probability of the assessment unit.

3. Worksheet Unc2: Unconditional-2 resource estimates, risked using both the geologic and the access ("geoacc") probability of the assessment unit.

4. Worksheet Numb: Input data (Panel 47), probability distribution calculations (Panels 48-54) for the number of potential cells.

The individual panel numbers and contents of the spreadsheet ACCESS are given in table 1. A probability system is an orderly collection of random variables that are logically related in terms of their probability distributions and parameters. The spreadsheet-probability system ACCESS includes:

Conditional (unrisked) and unconditional (risked) estimates of undeveloped petroleum resources (potential additions to reserves) in

1. Assessment unit

2. Parcel (or land entity)

3. Offshore portion of parcel

The total number of new random variables or sets of estimates (mean, standard deviation, F95, and F5) per assessment unit:

1. $72(2 \times 4 \times 3 \times 3)$ if one parcel

2. $120(2 \times 4 \times 3 \times 5)$ if two parcels

For illustrative purposes, the ACCESS system is used here to compute the estimates of undeveloped petroleum resources for two assessment units. Note that these two assessment units were used as examples of the basic input data form for the FORSPAN model in figs. 1 and 2. The computer printout of the 54 panels in the ACCESS spreadsheet for this illustration is presented on the following pages. The panel captions explain how the panels are related with respect to their calculations. Examples of particular interest are:

Panel 11. Conditional estimates of undeveloped resources in assessment unit: oil in oil fields and gas in gas fields. Mean, standard deviation, minimum, and maximum are computed by combining 
parameters from Panels 5 and 6. Fractiles F95, F75, F50, F25, and F5 are approximated by a lognormal distribution.

Note that the number of potential cells (Panel 5) and the total recovery per cell (Panel 6) produce the estimates for an assessment unit (Panel 11). The corresponding mathematical equations were given in the previous section.

Panel 23. Unconditional-1 estimates of undeveloped resources in assessment unit: oil in oil fields and gas in gas fields. Mean, standard deviation, minimum, and maximum are computed by applying the geologic probability from Panel 23 to parameters from Panel 11. Fractiles F95, F75, F50, F25, and F5 are approximated by a lognormal distribution.

Note that the geologic probability (Panel 23) is applied to the conditional estimates (Panel 11) to generate the unconditional-1 (risked for geology) estimates (Panel 23).

Panel 35. Unconditional-2 estimates of undeveloped resources in assessment unit: oil in oil fields and gas in gas fields. Mean, standard deviation, minimum, and maximum are computed by applying the geoacc probability from Panel 35 to parameters from Panel 11. Fractiles F95, F75, F50, F25, and F5 are approximated by a lognormal distribution.

Note that the geoacc probability (Panel 35) is applied to the conditional estimates (Panel 11) to generate the unconditional-2 (risked for geology and access) estimates (Panel 35).

\section{Versions}

Several versions of ACCESS exist. The unnumbered version, originally described in Open-File 00-044, was not used for any official USGS assessments. The first version actually used for assessments is here termed "version 1," which was used from 2000 to 2002 . Version 1 differed from the previous version in that it included a variable for "Percentage of total assessment-unit area that is untested" (line 3). Each triangular distribution was described by the minimum, median, and maximum. Version 2 was used from 2003 to 2008 . Each triangular distribution was described by the minimum, mode, and maximum. Version 3 was used from 2009 to 2011 . It corrected an error in version 2 by which the gas-oil ratio in oil fields was set as a triangle with minimum, mode, and maximum as 240,320 , and 960 , ignoring any input on panel 3. Otherwise, version 3 is the same as version 2. Examples given in this revised report are from ACCESS version 3.

Copies of the Microsoft Excel workbooks for versions 1 and 3 are included as part of this report.

\section{Acknowledgments}

The author wishes to acknowledge the helpful reviews of T.S. Dyman, J.W. Schmoker, T.A. Cook, and C.J. Schenk of the USGS.

\section{References Cited}

Aitchison, J., and Brown, J.A.C., 1957, The lognormal distribution: Cambridge, Cambridge University Press, $176 \mathrm{p}$.

Crovelli, R.A., 1992, Probabilistic methodology for estimation of undiscovered petroleum resources in play analysis of the United States: Nonrenewable Resources, v. 1, p. 153-162.

Crovelli, R.A., 1999, Probabilistic method for subdividing petroleum resources into depth slices: U.S. Geological Survey Open-File Report 99-343, 9 p. 
Law, A.M., and Kelton, W.D., 1991, Simulation modeling and analysis (2d ed): New York, McGraw-Hill, Inc., 759 p.

Ross, S.M., 1993, Introduction to probability models (5th ed): New York, Academic Press, Inc., 556 p. Schmoker, J.W., 1999, U.S. Geological Survey assessment model for continuous (unconventional) oil and gas accumulations_-The "FORSPAN" model: U.S. Geological Survey Bulletin 2168, 9 p. 
Table 1. Spreadsheet ACCESS panel numbers and contents. (NGL, natural gas liquids; Cond., conditional; Unc1., Unconditional 1; Unc2., Unconditional 2; Numb., define here)

(1) Input data: Assessment-unit probabilities

(2) Input data: Total recovery per cell

(3) Input data: Ratios used to assess coproducts

(4) Input data: Percent allocation to parcel and offshore portion of parcel

(5) Number of potential cells: Computed parameters

(6) Total recovery per cell: Truncated shifted lognormal distribution

(7) Ratios used to assess coproducts: Triangular distribution

(8) Ratios used to assess coproducts: Triangular distribution

(9) Percent allocation to parcel: Triangular distribution

(10) Percent allocation to offshore: Triangular distribution

(11) Cond. estimates in assessment unit: Oil in oil fields and gas in gas fields

(12) Cond. estimates in assessment unit: Gas in oil fields and NGL in gas fields

(13) Cond. estimates in assessment unit: NGL in oil fields and oil in gas fields

(14) Cond. estimates in assessment unit: Total in oil fields and total in gas fields

(15) Cond. allocation to parcel: Oil in oil fields and gas in gas fields

(16) Cond. allocation to parcel: Gas in oil fields and NGL in gas fields

(17) Cond. allocation to parcel: NGL in oil fields and oil in gas fields

(18) Cond. allocation to parcel: Total in oil fields and total in gas fields

(19) Cond. allocation to offshore: Oil in oil fields and gas in gas fields

(20) Cond. allocation to offshore: Gas in oil fields and NGL in gas fields

(21) Cond. allocation to offshore: NGL in oil fields and oil in gas fields

(22) Cond. allocation to offshore: Total in oil fields and total in gas fields

(23) Unc1. estimates in assessment unit: Oil in oil fields and gas in gas fields

(24) Unc1. estimates in assessment unit: Gas in oil fields and NGL in gas fields

(25) Unc1. estimates in assessment unit: NGL in oil fields and oil in gas fields

(26) Unc1. estimates in assessment unit: Total in oil fields and total in gas fields

(27) Unc1. allocation to parcel: Oil in oil fields and gas in gas fields

(28) Unc1. allocation to parcel: Gas in oil fields and NGL in gas fields

(29) Unc1. allocation to parcel: NGL in oil fields and oil in gas fields

(30) Unc1. allocation to parcel: Total in oil fields and total in gas fields

(31) Unc1. allocation to offshore: Oil in oil fields and gas in gas fields

(32) Unc1. allocation to offshore: Gas in oil fields and NGL in gas fields

(33) Unc1. allocation to offshore: NGL in oil fields and oil in gas fields

(34) Unc1. allocation to offshore: Total in oil fields and total in gas fields

(35) Unc2. estimates in assessment unit: Oil in oil fields and gas in gas fields

(36) Unc2. estimates in assessment unit: Gas in oil fields and NGL in gas fields

(37) Unc2. estimates in assessment unit: NGL in oil fields and oil in gas fields

(38) Unc2. estimates in assessment unit: Total in oil fields and total in gas fields

(39) Unc2. allocation to parcel: Oil in oil fields and gas in gas fields

(40) Unc2. allocation to parcel: Gas in oil fields and NGL in gas fields

(41) Unc2. allocation to parcel: NGL in oil fields and oil in gas fields

(42) Unc2. allocation to parcel: Total in oil fields and total in gas fields

(43) Unc2. allocation to offshore: Oil in oil fields and gas in gas fields

(44) Unc2. allocation to offshore: Gas in oil fields and NGL in gas fields

(45) Unc2. allocation to offshore: NGL in oil fields and oil in gas fields

(46) Unc2. allocation to offshore: Total in oil fields and total in gas fields

(47) Numb. input data: Assess.-unit area, potential percentage, and area per cell

(48) Numb. assessment-unit area: Triangular distribution

(49) Numb. potential percentage: Triangular distribution

(50) Numb. area per cell: Triangular distribution

(51) Numb. potential area: Lognormal distribution

(52) Numb. number of potential cells: Lognormal distribution 


\section{ACCESS}

\begin{tabular}{|c|c|c|c|c|c|c|c|}
\hline \multicolumn{5}{|c|}{ ACCESS: Analytic Cell-based Continuous Energy Spreadsheet System } & & \multicolumn{2}{|c|}{ R.A. Crovelli (Panel 1) } \\
\hline \multicolumn{3}{|c|}{ Assessment Unit } & \multicolumn{5}{|c|}{ Assessment-Unit Probabilities } \\
\hline Name & No. & Fields & Charge & Rocks & Timing & Geologic Access & GeoAcc \\
\hline Eagle Ford Shale Oil & 50490170 & Oil & 1 & 1 & 1 & 1 & 1 \\
\hline Woodford Shale Gas & 50620261 & Gas & 1 & 1 & 1 & 1 & 1 \\
\hline
\end{tabular}

Panel 1. Input data: assessment-unit name, number, and probabilities for charge, rocks, timing, and access. Geologic probability is the product of charge, rocks, and timing probabilities. "Geoacc" probability is the product of geologic and access probabilities.

\begin{tabular}{|l|l|r|r|r|r|}
\hline & & & & \multicolumn{2}{c|}{ Panel 2) } \\
\hline & & & & \multicolumn{2}{c|}{ Total Recovery Per Cell } \\
\hline No. & Fields & & \multicolumn{2}{c|}{ Oil (mmbo) and Gas (bcfg) } \\
\hline 50490170 Oil & See Panel 47 for input data & 0.002 & 0.03 & 10 \\
\hline 50620261 & Gas & See Panel 47 for input data & 0.02 & 0.5 & 10 \\
\hline
\end{tabular}

Panel 2. Input data: total recovery per cell-minimum, mode, and maximum. See Panel 47 for input data pertaining to the number of potential cells.

\begin{tabular}{|c|c|c|c|c|c|c|c|c|}
\hline & & & & & & & & (Panel 3) \\
\hline & Oil fields: & \multicolumn{3}{|c|}{ Gas/oil ratio (cfg/bo) } & \multicolumn{3}{|c|}{ NGL/gas ratio (bngl/mmcfg) } & \\
\hline & Gas fields: & \multicolumn{3}{|c|}{ NGL/gas ratio (bngl/mmcfg) } & \multicolumn{3}{|c|}{ Oil/gas ratio (bo/mmcfg) } & \\
\hline No. & Fields & Minimum & Mode & Maximum & Minimum & Mode & Maximum & \\
\hline 50490170 & Oil & 1000 & 2000 & 3000 & 10 & 20 & 30 & \\
\hline 50620261 & Gas & 0 & 0 & 40 & 0 & 0 & 0 & \\
\hline
\end{tabular}

Panel 3. Input data: ratios used to assess coproducts of undeveloped oil and gas fields - minimum, mode, and maximum. 


\begin{tabular}{|l|l|r|r|r|r|r|r|r|}
\hline & & & & & & (Panel 4) \\
\hline & & & \multicolumn{5}{c|}{ Percent Allocation } \\
\hline Parcel & Fields & Minimum & Mode & Maximum & Minimum & Mode & Maximum \\
\hline Texas & Oil & 58.88 & 58.88 & 58.88 & 0 & 0 & 0 \\
\hline Oklahoma & Gas & 85 & 85 & 85 & 0 & 0 & 0 \\
\hline
\end{tabular}

Panel 4. Input data: percent allocation to parcel and offshore portion of parcel—minimum, mode, and maximum.

\begin{tabular}{|c|c|c|c|c|c|c|}
\hline & & & & & & (Panel 5) \\
\hline & & & & & & \\
\hline & & \multicolumn{5}{|c|}{ Number of Potential Untested Cells } \\
\hline No. & Flds & Min,F100 & & Max,F0 & Mean & S.D. \\
\hline 50490170 & Oil & 232 & See Panels $48-54$ for calculations & 90605 & 15444.38 & 7976.192 \\
\hline 50620261 & Gas & 1740 & See Panels $48-54$ for calculations & 73173 & 13609.1 & 4377.83 \\
\hline
\end{tabular}

Panel 5. Number of potential untested cells: computed parameters are imported from Panel 54. See Panels 48-54 for sequence of calculations.

\begin{tabular}{|c|c|c|c|c|c|c|c|c|c|c|}
\hline & & & & & & & & & & (Panel 6) \\
\hline & & & & & & & & & & \\
\hline & & \multicolumn{9}{|c|}{ Total Recovery Per Cell (mmbo and bcfg) -- Truncated Shifted Lognormal Distribution } \\
\hline No. & Flds & Min,F100 I & Med,F50 & $\mathrm{Mu}$ & Sigma & $E(X)$ & $\mathrm{E}\left(\mathrm{X}^{\wedge} 2\right)$ & Max, F0 & Mean & S.D. \\
\hline 50490170 & Oil & 0.002 & 0.03 & -3.57555 & 1.15649 & 0.053255 & 0.008905 & 1 & 0.055255 & 0.077902 \\
\hline 50620261 & Gas & 0.02 & 0.5 & -0.73397 & 0.98206 & 0.764647 & 1.381312 & 10 & 0.784647 & 0.89254 \\
\hline
\end{tabular}

Panel 6. Total recovery per cell: truncated shifted lognormal distribution. Mean and standard deviation are computed. 


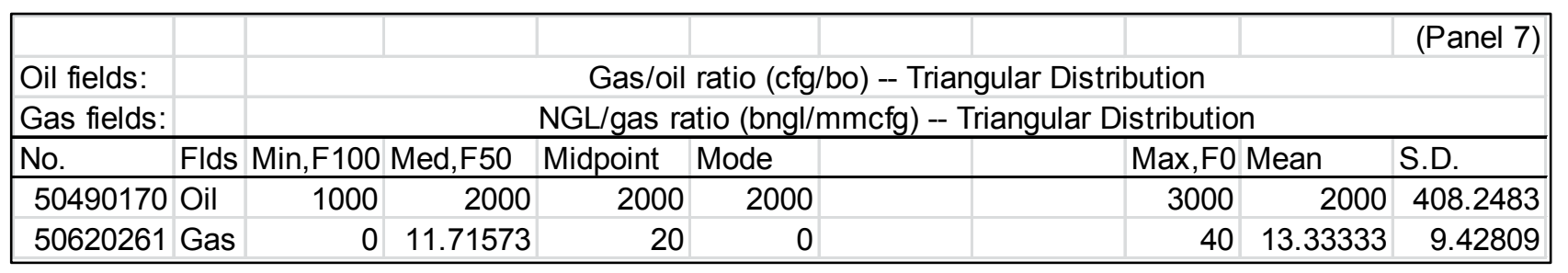

Panel 7. Ratios used to assess coproducts: triangular distribution. Midpoint, median, mean, and standard deviation are computed.

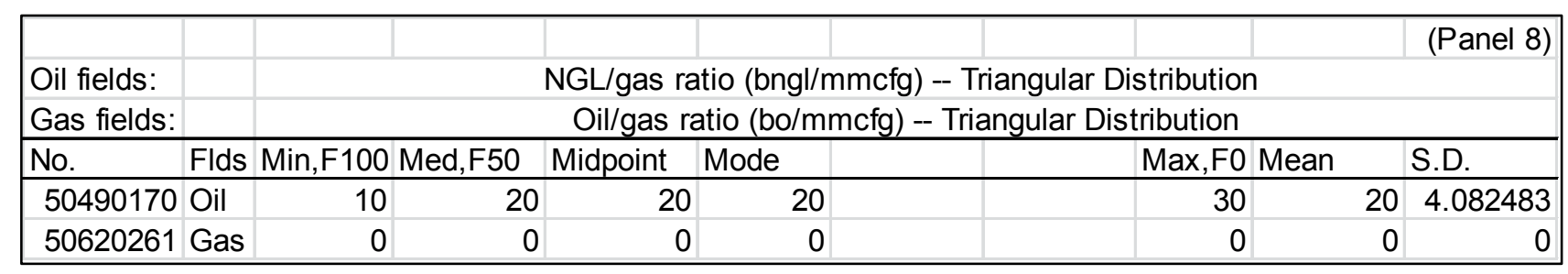

Panel 8. Ratios used to assess coproducts: triangular distribution. Midpoint, median, mean, and standard deviation are computed.

\begin{tabular}{|l|r|r|r|r|r|r|r|r|}
\hline \multicolumn{8}{|c|}{ Percent Allocation of Undeveloped Resources by Volume to Parcel } & (Panel 9) \\
\hline \multicolumn{8}{|c|}{ Percent Resources in Oil/Gas Fields -- Triangular Distribution } \\
\hline Parcel & Flds Min,F100 Med,F50 & Midpoint & Mode & Max,F0 Mean & S.D. \\
\hline Texas & "Oil & 58.88 & 58.88 & 58.88 & 58.88 & 58.88 & 58.88 & 0 \\
\hline Oklahoma "Gas & 85 & 85 & 85 & 85 & 85 & 85 & 0 \\
\hline
\end{tabular}

Panel 9. Percent allocation of undeveloped resources by volume to parcel: triangular distribution. Midpoint, median, mean, and standard deviation are computed. 


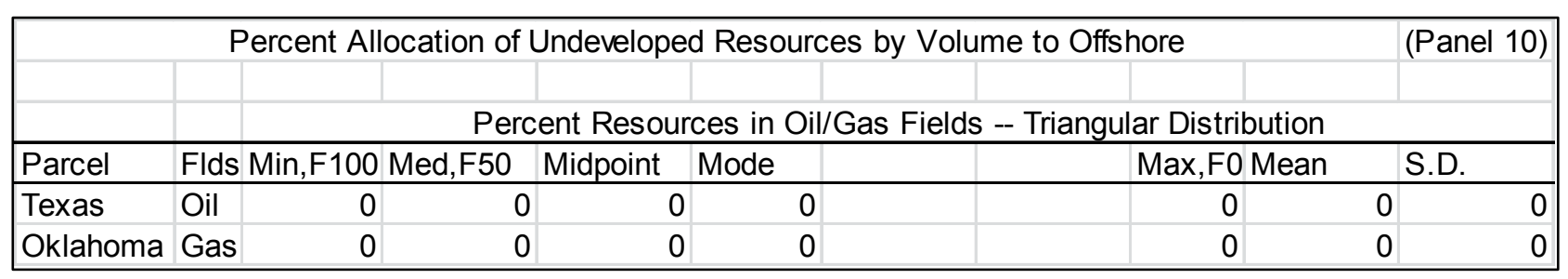

Panel 10. Percent allocation of undeveloped resources by volume to offshore portion of parcel: triangular distribution. Midpoint, median, mean, and standard deviation are computed.

\begin{tabular}{|c|c|c|c|c|c|c|c|c|c|c|}
\hline \multicolumn{10}{|c|}{ CONDITIONAL ESTIMATES OF UNDEVELOPED RESOURCES IN ASSESSMENT UNIT } & \multirow[t]{2}{*}{ (Panel 11) } \\
\hline & & \multirow{2}{*}{\multicolumn{9}{|c|}{$\begin{array}{l}\text { Oil in Oil Fields (mmbo) } \\
\text { Gas in Gas Fields (bcfa) }\end{array}$}} \\
\hline & & & & & & & & & & \\
\hline No. & Flds & Mean & S.D. & Min,F100 & F95 & F75 & Med,F50 & F25 & F5 & Max,F0 \\
\hline 50490170 & Oil & 853.382 & 440.8324 & 0.464 & 340.6918 & 546.1581 & 758.196 & 1052.555 & 1687.336 & 90605 \\
\hline 50620261 & Gas & 10678.33 & 3436.627 & 34.8 & 6065.16 & 8225.118 & 10164.9 & 12562.11 & 17035.8 & 731730 \\
\hline
\end{tabular}

Panel 11. Conditional estimates of undeveloped resources in assessment unit: oil in oil fields and gas in gas fields. Mean, standard deviation, minimum, and maximum are computed by combining parameters from Panels 5 and 6. Fractiles F95, F75, F50, F25, and F5 are approximated by a lognormal distribution.

\begin{tabular}{|c|c|c|c|c|c|c|c|c|c|c|}
\hline \multicolumn{10}{|c|}{ CONDITIONAL ESTIMATES OF UNDEVELOPED RESOURCES IN ASSESSMENT UNIT } & (Panel 12) \\
\hline & & \multicolumn{9}{|c|}{ Gas in Oil Fields (bcfg) } \\
\hline & & \multicolumn{9}{|c|}{ NGL in Gas Fields (mmbngl) } \\
\hline No. & Flds & Mean & S.D. & Min,F100 F & F95 & $\mathrm{F} 75$ & Med,F50 & $\mathrm{F} 25$ & F5 & Max,F0 \\
\hline 50490170 & Oil & 1706.764 & 964.9344 & 0.464 & 624.7984 & 1041.548 & 1485.76 & 2119.41 & 3533.089 & 271815 \\
\hline 50620261 & Gas & 142.3778 & 115.2613 & 0 & 34.42281 & 68.55412 & 110.661 & 178.6312 & 355.7498 & 29269 \\
\hline
\end{tabular}

Panel 12. Conditional estimates of undeveloped resources in assessment unit: gas in oil fields and NGL in gas fields. Mean, standard deviation, minimum, and maximum are computed by combining parameters from Panels 7 and 11. Fractiles F95, F75, F50, F25, and F5 are approximated by a lognormal distribution. 


\begin{tabular}{|c|c|c|c|c|c|c|}
\hline \multicolumn{6}{|c|}{ CONDITIONAL ESTIMATES OF UNDEVELOPED RESOURCES IN ASSESSMENT UNIT } & (Panel 13) \\
\hline & & \multicolumn{5}{|c|}{ NGL in Oil Fields (mmbngl) } \\
\hline & & \multicolumn{5}{|c|}{ Oil in Gas Fields (mmbo) } \\
\hline No. & Flds & Mean & Min,F100 F95 & Med,F50 F25 & F5 & Max,F0 \\
\hline 50490170 & Oil & $\begin{array}{ll}34.13528 & 20.89278\end{array}$ & $\begin{array}{lll}0.00464 & 11.5125 & 19.90131\end{array}$ & $29.1147 \quad 42.59357$ & 73.63023 & 8154.5 \\
\hline 50620261 & Gas & 0 & 0 \#DIV/0! & \#DIV/O! \#DIV/0! & \#DIV/0! & 0 \\
\hline
\end{tabular}

Panel 13. Conditional estimates of undeveloped resources in assessment unit: NGL in oil fields and oil in gas fields. Mean, standard deviation, minimum, and maximum are computed by combining parameters from Panels 8 and 12 for NGL in oil fields and parameters from Panels 8 and 11 for oil in gas fields. Fractiles F95, F75, F50, F25, and F5 are approximated by a lognormal distribution.

\begin{tabular}{|l|r|r|r|r|r|r|r|r|r|}
\hline \multicolumn{8}{|c|}{ CONDITIONAL ESTIMATES OF UNDEVELOPED RESOURCES IN ASSESSMENT UNIT } & (Panel 14) \\
\hline \multicolumn{8}{|c|}{ Total Resources in Oil Fields (mmbo \& mmboe \& mmbngl) } \\
\hline \\
\hline
\end{tabular}

Panel 14. Conditional estimates of undeveloped resources in assessment unit: total resources in oil fields and total resources in gas fields. Mean, standard deviation, minimum, and maximum are computed by combining parameters from Panels 7, 8, and 11. Fractiles F95, F75, F50, F25, and F5 are approximated by a lognormal distribution.

\begin{tabular}{|l|l|l|r|r|r|r|r|r|r|}
\hline \multicolumn{8}{|c|}{ CONDITIONAL ALLOCATION OF UNDEVELOPED RESOURCES TO PARCEL } \\
Oil in Oil Fields (mmbo) \\
\hline \\
\hline
\end{tabular}

Panel 15. Conditional allocation of undeveloped resources to parcel: oil in oil fields and gas in gas fields. Mean, standard deviation, minimum, and maximum are computed by applying parameters from Panel 9 to parameters from Panel 11. Fractiles F95, F75, F50, F25, and F5 are approximated by a lognormal distribution. 


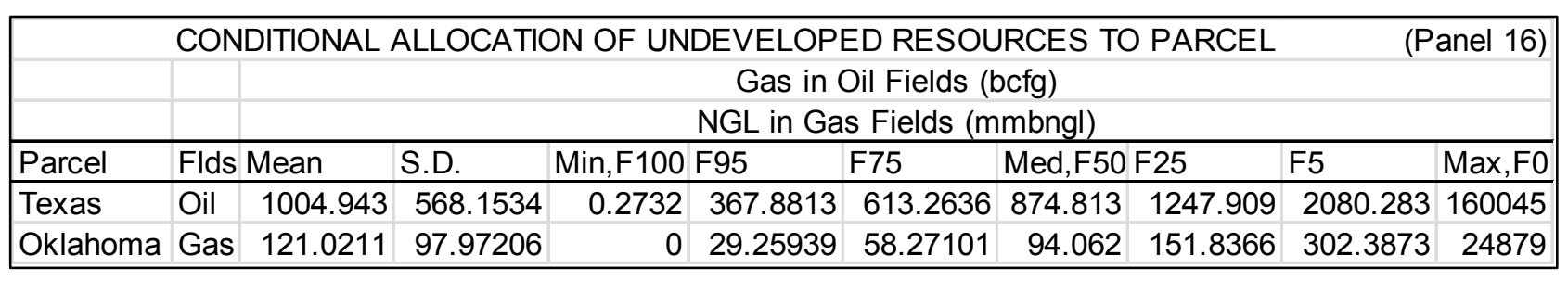

Panel 16. Conditional allocation of undeveloped resources to parcel: gas in oil fields and NGL in gas fields. Mean, standard deviation, minimum, and maximum are computed by applying parameters from Panel 9 to parameters from Panel 12. Fractiles F95, F75, F50, F25, and F5 are approximated by a lognormal distribution.

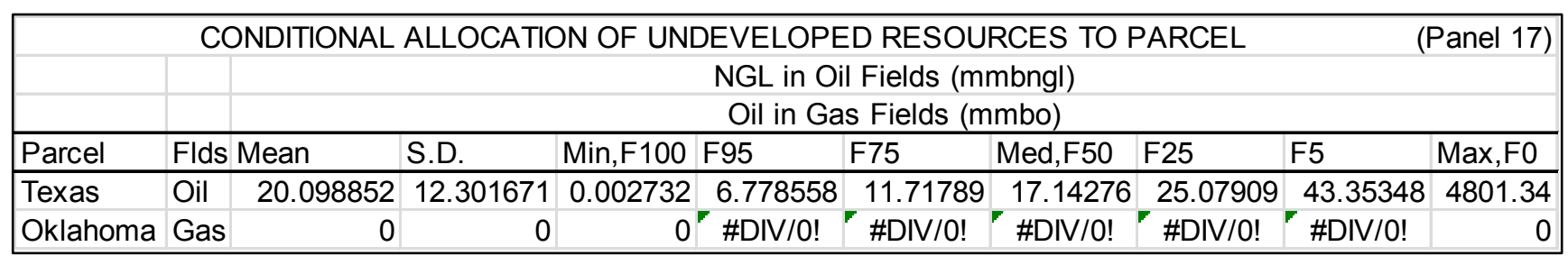

Panel 17. Conditional allocation of undeveloped resources to parcel: NGL in oil fields and oil in gas fields. Mean, standard deviation, minimum, and maximum are computed by applying parameters from Panel 9 to parameters from Panel 13. Fractiles F95, F75, F50, F25, and F5 are approximated by a lognormal distribution. Cells with "\#DIV/0!" are not calculated because the distribution is not lognormal.

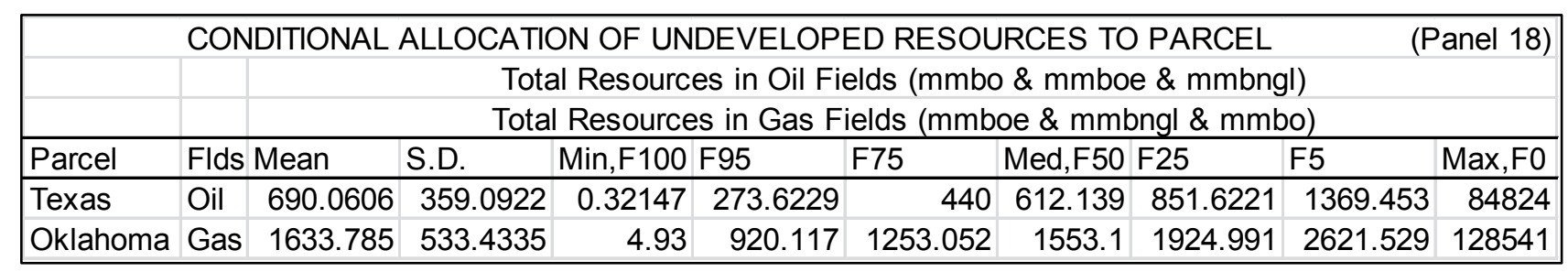

Panel 18. Conditional allocation of undeveloped resources to parcel: total resources in oil fields and total resources in gas fields. Mean, standard deviation, minimum, and maximum are computed by applying parameters from Panel 9 to parameters from Panel 14. Fractiles F95, F75, F50, F25, and F5 are approximated by a lognormal distribution. 


\begin{tabular}{|c|c|c|c|c|c|c|c|c|c|c|}
\hline \multicolumn{10}{|c|}{ CONDITIONAL ALLOCATION OF UNDEVELOPED RESOURCES TO OFFSHORE } & \multirow[t]{2}{*}{ (Panel 19) } \\
\hline & & \multicolumn{8}{|c|}{ Oil in Oil Fields (mmbo) } & \\
\hline & & \multicolumn{9}{|c|}{ Gas in Gas Fields (bcfg) } \\
\hline Parcel & Flds & s Mean & S.D. & & $00 \mathrm{F95}$ & $\mathrm{F} 75$ & Med,F50 & F25 & F5 & Max,F0 \\
\hline Texas & Oil & & 0 & 0 & 0 \#DIV/0! & \#DIV/0! & \#DIV/0! & \#DIV/O! & \#DIV/O! & 0 \\
\hline Oklahoma & Gas & & 0 & 0 & 0 \#DIV/0! & \#DIV/O! & \#DIV/O! & \#DIV/O! & \#DIV/0! & 0 \\
\hline
\end{tabular}

Panel 19. Conditional allocation of undeveloped resources to offshore portion of parcel: oil in oil fields and gas in gas fields. Mean, standard deviation, minimum, and maximum are computed by applying parameters from Panel 10 to parameters from Panel 15. Fractiles F95, F75, F50, F25, and F5 are approximated by a lognormal distribution. Cells with "\#DIV/0!" are not calculated because the distribution is not lognormal.

\begin{tabular}{|c|c|c|c|c|c|c|c|c|c|c|}
\hline \multicolumn{10}{|c|}{ CONDITIONAL ALLOCATION OF UNDEVELOPED RESOURCES TO OFFSHORE } & \multirow{2}{*}{ (Panel 20) } \\
\hline & & \multicolumn{8}{|c|}{ Gas in Oil Fields (bcfg) } & \\
\hline & & \multicolumn{9}{|c|}{ NGL in Gas Fields (mmbngl) } \\
\hline Parcel & Flds & Mean & S.D. & Min,F100 & F95 & F75 & Med,F50 & $\mathrm{F} 25$ & F5 & Max,F0 \\
\hline Texas & Oil & & 0 & 0 & 0 \#DIV/0! & \#DIV/0! & \#DIV/0! & \#DIV/0! & \#DIV/0! & 0 \\
\hline Oklahoma & Gas & & 0 & 0 & 0 \#DIV/0! & \#DIV/0! & \#DIV/O! & \#DIV/O! & \#DIV/O! & 0 \\
\hline
\end{tabular}

Panel 20. Conditional allocation of undeveloped resources to offshore portion of parcel: gas in oil fields and NGL in gas fields. Mean, standard deviation, minimum, and maximum are computed by applying parameters from Panel 10 to parameters from Panel 16. Fractiles F95, F75, F50, F25, and F5 are approximated by a lognormal distribution. Cells with "\#DIV/0!" are not calculated because the distribution is not lognormal.

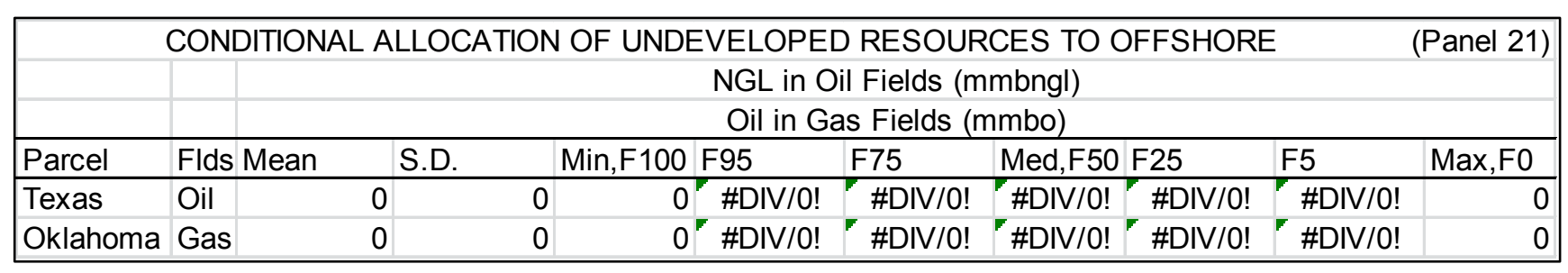

Panel 21. Conditional allocation of undeveloped resources to offshore portion of parcel: NGL in oil fields and oil in gas fields. Mean, standard deviation, minimum, and maximum are computed by applying parameters from Panel 10 to parameters from Panel 17. Fractiles F95, F75, F50, F25, and F5 are approximated by a lognormal distribution. Cells with "\#DIV/0!" are not calculated because the distribution is not lognormal. 


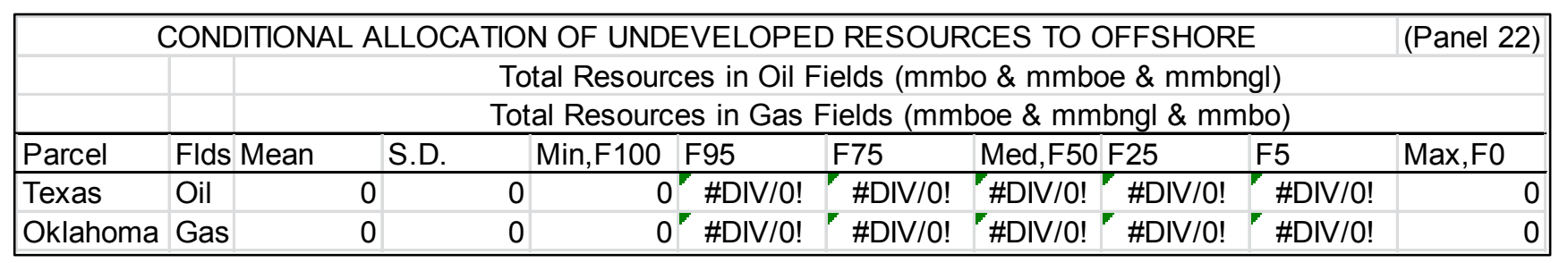

Panel 22. Conditional allocation of undeveloped resources to offshore portion of parcel: total resources in oil fields and total resources in gas fields. Mean, standard deviation, minimum, and maximum are computed by applying parameters from Panel 10 to parameters from Panel 18. Fractiles F95, F75, F50, F25, and F5 are approximated by a lognormal distribution. Cells with "\#DIV/0!" are not calculated because the distribution is not lognormal.

\begin{tabular}{|c|c|c|c|c|c|c|c|c|c|c|c|}
\hline & \multicolumn{10}{|c|}{ UNCONDITIONAL ESTIMATES OF UNDEVELOPED RESOURCES IN ASSESSMENT UNIT } & \multirow[t]{2}{*}{ (Panel 23) } \\
\hline & & & \multirow{2}{*}{\multicolumn{9}{|c|}{$\begin{array}{l}\text { Oil in Oil Fields (mmbo) } \\
\text { Gas in Gas Fields (bcfa) }\end{array}$}} \\
\hline Probab & & & & & & & & & & & \\
\hline \multicolumn{2}{|c|}{ Geologic No. } & Flds & Mean & S.D. & Min,F100 & F95 & F75 & Med,F50 & F25 & F5 & Max,F0 \\
\hline & 50490170 & Oil & 853.382 & 440.8324 & 0.464 & 340.6918 & 546.1581 & 758.196 & 1052.555 & 1687.336 & 90605 \\
\hline & 50620261 & Gas & 10678.33 & 3436.627 & 34.8 & 6065.16 & 8225.118 & 10164.9 & 12562.11 & 17035.8 & 731730 \\
\hline
\end{tabular}

Panel 23. Unconditional-1 estimates of undeveloped resources in assessment unit: oil in oil fields and gas in gas fields. Mean, standard deviation, minimum, and maximum are computed by applying the geologic probability from Panel 23 to parameters from Panel 11. Fractiles F95, F75, F50, F25, and F5 are approximated by a lognormal distribution.

\begin{tabular}{|l|l|l|l|r|r|r|r|r|r|r|}
\hline \multicolumn{8}{|c|}{ UNCONDITIONAL ESTIMATES OF UNDEVELOPED RESOURCES IN ASSESSMENT UNIT } & (Panel 24) \\
Gas in Oil Fields (bcfg) \\
\hline
\end{tabular}

Panel 24. Unconditional-1 estimates of undeveloped resources in assessment unit: gas in oil fields and NGL in gas fields. Mean, standard deviation, minimum, and maximum are computed by applying the geologic probability from Panel 23 to parameters from Panel 12. Fractiles F95, F75, F50, F25, and F5 are approximated by a lognormal distribution. 


\begin{tabular}{|c|c|c|c|c|c|c|c|}
\hline \multicolumn{7}{|c|}{ UNCONDITIONAL ESTIMATES OF UNDEVELOPED RESOURCES IN ASSESSMENT UNIT } & (Panel 25) \\
\hline & & \multicolumn{6}{|c|}{ NGL in Oil Fields (mmbngl) } \\
\hline & & \multicolumn{6}{|c|}{ Oil in Gas Fields (mmbo) } \\
\hline No. & Flds & Mean & Min,F100 F95 & F75 & Med,F50 F25 & F5 & Max,F0 \\
\hline 50490170 & Oil & $\begin{array}{ll}34.13528 & 20.89278\end{array}$ & $\begin{array}{lll}0.00464 & 11.51249738\end{array}$ & 19.90131 & \begin{tabular}{|l|l|}
29.1147 & 42.59357 \\
\end{tabular} & 73.63023 & 8154.5 \\
\hline 50620261 & 1 Gas & 0 & \#DIV/0! & \#DIV/0! & \#DIV/0! \#DIV/O! & \#DIV/O! & 0 \\
\hline
\end{tabular}

Panel 25. Unconditional-1 estimates of undeveloped resources in assessment unit: NGL in oil fields and oil in gas fields. Mean, standard deviation, minimum, and maximum are computed by applying the geologic probability from Panel 23 to parameters from Panel 13. Fractiles F95, F75, F50, F25, and F5 are approximated by a lognormal distribution. Cells with "\#DIV/0!" are not calculated because the distribution is not lognormal.

\begin{tabular}{|c|c|c|c|c|c|c|c|c|c|c|}
\hline \multicolumn{10}{|c|}{ UNCONDITIONAL ESTIMATES OF UNDEVELOPED RESOURCES IN ASSESSMENT UNIT } & (Panel 26) \\
\hline & & \multicolumn{9}{|c|}{ Total Resources in Oil Fields (mmbo \& mmboe \& mmbngl) } \\
\hline & & \multicolumn{9}{|c|}{ Total Resources in Gas Fields (mmboe \& mmbngl \& mmbo) } \\
\hline No. & Flds & Mean & S.D. & Min,F100 & F95 & F75 & Med,F50 & F25 & F5 & Max,F0 \\
\hline 50490170 & Oil & 1171.978 & 609.8713 & 0.54597 & 464.7129 & 747.2827 & 1039.64 & 1446.369 & 2325.837 & 144062 \\
\hline 50620261 & Gas & 1922.1 & 627.5688 & 5.8 & 1082.491 & 1474.179 & 1827.17 & 2264.695 & 3084.152 & 151224 \\
\hline
\end{tabular}

Panel 26. Unconditional-1 estimates of undeveloped resources in assessment unit: total resources in oil fields and total resources in gas fields. Mean, standard deviation, minimum, and maximum are computed by applying the geologic probability from Panel 23 to parameters from Panel 14. Fractiles F95, F75, F50, F25, and F5 are approximated by a lognormal distribution.

\begin{tabular}{|l|l|l|r|r|r|r|r|r|r|}
\hline \multicolumn{8}{|c|}{ UNCONDITIONAL ALLOCATION OF UNDEVELOPED RESOURCES TO PARCEL } \\
Oil in Oil Fields (mmbo) \\
\hline
\end{tabular}

Panel 27. Unconditional-1 allocation of undeveloped resources to parcel: oil in oil fields and gas in gas fields. Mean, standard deviation, minimum, and maximum are computed by applying the geologic probability from Panel 23 to parameters from Panel 15. Fractiles F95, F75, F50, F25, and F5 are approximated by a lognormal distribution. 


\begin{tabular}{|c|c|c|c|c|c|c|c|c|c|c|}
\hline \multicolumn{9}{|c|}{ UNCONDITIONAL ALLOCATION OF UNDEVELOPED RESOURCES TO PARCEL } & \multirow{2}{*}{\multicolumn{2}{|c|}{ (Panel 28) }} \\
\hline & & \multicolumn{7}{|c|}{ Gas in Oil Fields (bcfg) } & & \\
\hline & & \multicolumn{9}{|c|}{ NGL in Gas Fields (mmbngl) } \\
\hline Parcel & FIds 1 & Mean & S.D. & Min,F100 & F95 & F75 & Med,F50 & F25 & F5 & Max,F0 \\
\hline Texas & Oil & 1004.943 & 568.1534 & 0.273203 & 367.8813 & 613.2636 & 874.813 & 1247.909 & 2080.283 & 160045 \\
\hline Oklahoma & Gas & 121.0211 & 97.97206 & 0 & 29.25939 & 58.27101 & 94.062 & 151.8366 & 302.3873 & 24878.8 \\
\hline
\end{tabular}

Panel 28. Unconditional-1 allocation of undeveloped resources to parcel: gas in oil fields and NGL in gas fields. Mean, standard deviation, minimum, and maximum are computed by applying the geologic probability from Panel 23 to parameters from Panel 16. Fractiles F95, F75, F50, F25, and F5 are approximated by a lognormal distribution.

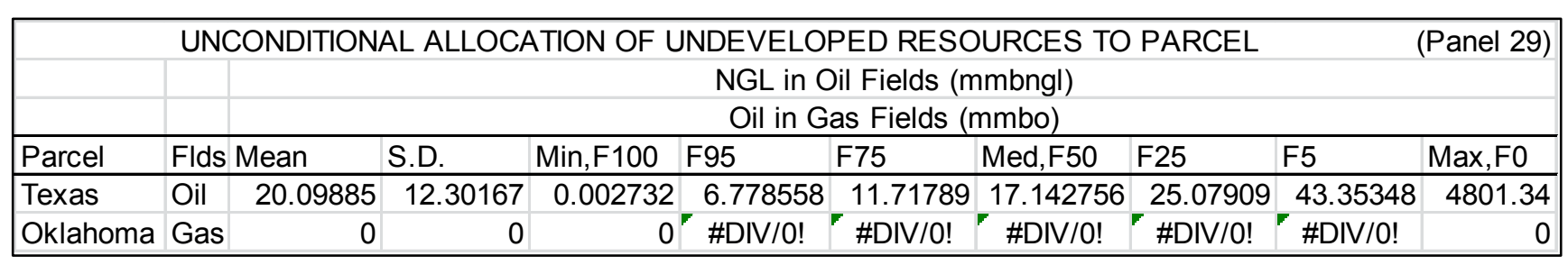

Panel 29. Unconditional-1 allocation of undeveloped resources to parcel: NGL in oil fields and oil in gas fields. Mean, standard deviation, minimum, and maximum are computed by applying the geologic probability from Panel 23 to parameters from Panel 17. Fractiles F95, F75, F50, F25, and F5 are approximated by a lognormal distribution. Cells with “\#DIV/0!" are not calculated because the distribution is not lognormal.

\begin{tabular}{|l|l|l|r|r|r|r|r|r|r|}
\hline \multicolumn{8}{|c|}{ UNCONDITIONAL ALLOCATION OF UNDEVEOPED RESOURCES TO PARCEL } \\
Total Resources in Oil Fields (mmbo \& mmboe \& mmbngl) \\
Total Resources in Gas Fields (mmboe \& mmbngl \& mmbo)
\end{tabular}

Panel 30. Unconditional-1 allocation of undeveloped resources to parcel: total resources in oil fields and total resources in gas fields. Mean, standard deviation, minimum, and maximum are computed by applying the geologic probability from Panel 23 to parameters from Panel 18. Fractiles F95, F75, F50, F25, and F5 are approximated by a lognormal distribution. 


\begin{tabular}{|c|c|c|c|c|c|c|c|c|c|}
\hline \multicolumn{9}{|c|}{ UNCONDITIONAL ALLOCATION OF UNDEVELOPED RESOURCES TO OFFSHORE } & \multirow[t]{2}{*}{ (Panel 31) } \\
\hline & & \multicolumn{7}{|c|}{ Oil in Oil Fields $(\mathrm{mmbo})$} & \\
\hline & & \multicolumn{8}{|c|}{ Gas in Gas Fields (bcfg) } \\
\hline Parcel & Flds & s Mean & S.D. & Min,F100 F95 & F75 & Med,F50 & F25 & F5 & Max,F0 \\
\hline Texas & Oil & & 0 & 0 \#DIV/0! & \#DIV/0! & \#DIV/O! & \#DIV/O! & \#DIV/0! & 0 \\
\hline Oklahoma & Gas & & 0 & 0 \#DIV/0! & \#DIV/O! & \#DIV/0! & \#DIV/O! & \#DIV/0! & 0 \\
\hline
\end{tabular}

Panel 31. Unconditional-1 allocation of undeveloped resources to offshore portion of parcel: oil in oil fields and gas in gas fields. Mean, standard deviation, minimum, and maximum are computed by applying the geologic probability from Panel 23 to parameters from Panel 19. Fractiles F95, F75, F50, F25, and F5 are approximated by a lognormal distribution. Cells with "\#DIV/0!" are not calculated because the distribution is not lognormal.

\begin{tabular}{|l|l|l|l|l|l|l|l|r|}
\hline \multicolumn{8}{|c|}{ UNCONDITIONAL ALLOCATION OF UNDEVELOPED RESOURCES TO OFFSHORE } \\
Gas in Oil Fields (bcfg) \\
\hline
\end{tabular}

Panel 32. Unconditional-1 allocation of undeveloped resources to offshore portion of parcel: gas in oil fields and NGL in gas fields. Mean, standard deviation, minimum, and maximum are computed by applying the geologic probability from Panel 23 to parameters from Panel 20. Fractiles F95, F75, F50, F25, and F5 are approximated by a lognormal distribution. Cells with "\#DIV/0!" are not calculated because the distribution is not lognormal.

\begin{tabular}{|c|c|c|c|c|c|c|c|c|c|}
\hline \multicolumn{9}{|c|}{ UNCONDITIONAL ALLOCATION OF UNDEVELOPED RESOURCES TO OFFSHORE } & \multirow{2}{*}{ (Panel 33) } \\
\hline & & & & NGL ir & Oil Fields & nmbngl) & & & \\
\hline & \multicolumn{9}{|c|}{ Oil in Gas Fields (mmbo) } \\
\hline Parcel & Flds Mean & S.D. & Min,F100 & F95 & F75 & Med,F50 & F25 & F5 & Max,F0 \\
\hline Texas & Oil & 0 & 0 & 0 \#DIV/O! & \#DIV/O! & \#DIV/O! & \#DIV/0! & \#DIV/O! & 0 \\
\hline Oklahoma & Gas & 0 & 0 & 0 \#DIV/0! & \#DIV/0! & \#DIV/0! & \#DIV/0! & \#DIV/O! & 0 \\
\hline
\end{tabular}

Panel 33. Unconditional-1 allocation of undeveloped resources to offshore portion of parcel: NGL in oil fields and oil in gas fields. Mean, standard deviation, minimum, and maximum are computed by applying the geologic probability from Panel 23 to parameters from Panel 21. Fractiles F95, F75, F50, F25, and F5 are approximated by a lognormal distribution. Cells with "\#DIV/0!” are not calculated because the distribution is not lognormal. 


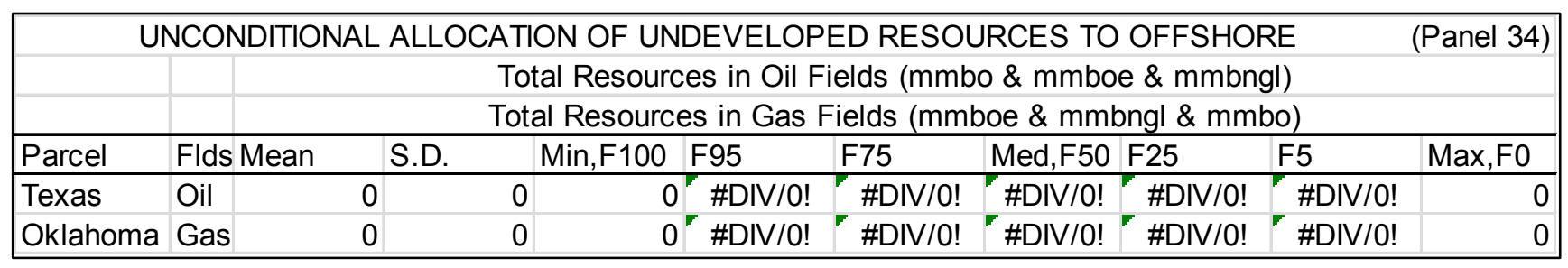

Panel 34. Unconditional-1 allocation of undeveloped resources to offshore portion of parcel: total resources in oil fields and total resources in gas fields. Mean, standard deviation, minimum, and maximum are computed by applying the geologic probability from Panel 23 to parameters from Panel 22. Fractiles F95, F75, F50, F25, and F5 are approximated by a lognormal distribution. Cells with "\#DIV/0!" are not calculated because the distribution is not lognormal.

\begin{tabular}{|c|c|c|c|c|c|c|c|c|c|c|c|}
\hline & \multicolumn{10}{|c|}{ UNCONDITIONAL ESTIMATES OF UNDEVELOPED RESOURCES IN ASSESSMENT UNIT } & \multirow{2}{*}{ (Panel 35) } \\
\hline & & & & & & Oil in $\mathrm{O}$ & Dil Fields $(\mathrm{m}$ & nmbo) & & & \\
\hline Probab & & & \multicolumn{9}{|c|}{ Gas in Gas Fields (bcfg) } \\
\hline GeoAcc & & Flds & Mean & S.D. & Min,F100 & F95 & F75 & Med,F50 & F25 & F5 & Max, F0 \\
\hline 1 & 50490170 & Oil & 853.382 & 440.8324 & 0.464 & 340.6918 & 546.1581 & 758.196 & 1052.555 & 1687.336 & 90605 \\
\hline 1 & 50620261 & Gas & 10678.33 & 3436.627 & 34.8 & 6065.16 & 8225.118 & 10164.9 & 12562.11 & 17035.8 & 3731730 \\
\hline
\end{tabular}

Panel 35. Unconditional-2 estimates of undeveloped resources in assessment unit: oil in oil fields and gas in gas fields. Mean, standard deviation, minimum, and maximum are computed by applying the geoacc probability from Panel 35 to parameters from Panel 11. Fractiles F95, F75, F50, F25, and F5 are approximated by a lognormal distribution.

\begin{tabular}{|c|c|c|c|c|c|c|c|c|c|}
\hline \multicolumn{9}{|c|}{ UNCONDITIONAL ESTIMATES OF UNDEVELOPED RESOURCES IN ASSESSMENT UNIT } & \multirow[t]{2}{*}{ (Panel 36) } \\
\hline & & \multicolumn{7}{|c|}{ Gas in Oil Fields (bcfg) } & \\
\hline & & \multicolumn{8}{|c|}{ NGL in Gas Fields (mmbngl) } \\
\hline No. & Flds & Mean & S.D. & Min,F100 & F95 & F75 & Med,F50 F25 & F5 & Max, F0 \\
\hline 50490170 & Oil & 1706.764 & 964.9344 & 0.464 & 624.7984 & 1041.548 & 1485.76 & 3533.089 & 271815 \\
\hline 50620261 & Gas & 142.3778 & 115.2613 & 0 & 34.42281 & 68.55412 & \begin{tabular}{|l|l|}
110.661 & 178.6312 \\
\end{tabular} & 355.7498 & 29269 \\
\hline
\end{tabular}

Panel 36. Unconditional-2 estimates of undeveloped resources in assessment unit: gas in oil fields and NGL in gas fields. Mean, standard deviation, minimum, and maximum are computed by applying the geoacc probability from Panel 35 to parameters from Panel 12. Fractiles F95, F75, F50, F25, and F5 are approximated by a lognormal distribution. 


\begin{tabular}{|c|c|c|c|c|c|c|}
\hline \multicolumn{6}{|c|}{ UNCONDITIONAL ESTIMATES OF UNDEVELOPED RESOURCES IN ASSESSMENT UNIT } & (Panel 37) \\
\hline & & \multicolumn{5}{|c|}{ NGL in Oil Fields (mmbngl) } \\
\hline & & \multicolumn{5}{|c|}{ Oil in Gas Fields (mmbo) } \\
\hline No. & Flds & Mean & Min,F100 F95 & \begin{tabular}{ll|l} 
Med,F50 F25 \\
\end{tabular} & F5 & Max,F0 \\
\hline 50490170 & Oil & $\begin{array}{lll}34.13528 & 20.89278 \\
\end{array}$ & $0.00464 \quad 11.512497 \quad 19.90131$ & $29.1147 \quad 42.59357$ & 73.63023 & 8154.5 \\
\hline 50620261 & Gas & 0 & 0 \#DIV/0! & \#DIV/O! \#DIV/0! & \#DIV/0! & 0 \\
\hline
\end{tabular}

Panel 37. Unconditional-2 estimates of undeveloped resources in assessment unit: NGL in oil fields and oil in gas fields. Mean, standard deviation, minimum, and maximum are computed by applying the geoacc probability from Panel 35 to parameters from Panel 13. Fractiles F95, F75, F50, F25, and F5 are approximated by a lognormal distribution. Cells with "\#DIV/0!" are not calculated because the distribution is not lognormal.

\begin{tabular}{|l|r|r|r|r|r|r|r|r|r|r|}
\hline \multicolumn{8}{|c|}{ UNCONDITIONAL ESTIMATES OF UNDEVELOPED RESOURCES IN ASSESSMENT UNIT } & (Panel 38) \\
\hline & \multicolumn{8}{|c|}{ Total Resources in Oil Fields (mmbo \& mmboe \& mmbngl) } \\
\hline No. & \multicolumn{8}{|c|}{ Total Resources in Gas Fields (mmboe \& mmbngl \& mmbo) } & \\
\hline 50490170 & Oil & 1171.978 & 609.8713 & 0.54597 & 464.7129 & 747.2827 & 1039.638 & 1446.369 & 2325.837 & 144062 \\
\hline 50620261 & Gas & 1922.1 & 627.5688 & 5.8 & 1082.491 & 1474.179 & 1827.174 & 2264.695 & 3084.152 & 151224 \\
\hline
\end{tabular}

Panel 38. Unconditional-2 estimates of undeveloped resources in assessment unit: total resources in oil fields and total resources in gas fields. Mean, standard deviation, minimum, and maximum are computed by applying the geoacc probability from Panel 35 to parameters from Panel 14. Fractiles F95, F75, F50, F25, and F5 are approximated by a lognormal distribution.

\begin{tabular}{|l|l|l|r|r|r|r|r|r|r|r|}
\hline \multicolumn{8}{|c|}{ UNCONDITIONAL ALLOCATION OF UNDEVELOPED RESOURCES TO PARCEL } \\
Oil in Oil Fields (mmbo) \\
\hline
\end{tabular}

Panel 39. Unconditional-2 allocation of undeveloped resources to parcel: oil in oil fields and gas in gas fields. Mean, standard deviation, minimum, and maximum are computed by applying the geoacc probability from Panel 35 to parameters from Panel 15. Fractiles F95, F75, F50, F25, and F5 are approximated by a lognormal distribution. 


\begin{tabular}{|c|c|c|c|c|c|c|c|c|c|c|}
\hline \multicolumn{9}{|c|}{ UNCONDITIONAL ALLOCATION OF UNDEVELOPED RESOURCES TO PARCEL } & \multicolumn{2}{|c|}{ (Panel 40) } \\
\hline & & \multicolumn{9}{|c|}{ Gas in Oil Fields (bcfg) } \\
\hline & & \multicolumn{9}{|c|}{ NGL in Gas Fields (mmbngl) } \\
\hline Parcel & Flds & Mean & S.D. & Min,F100 & F95 & F75 & Med,F50 & F25 & F5 & Max,F0 \\
\hline Texas & Oil & 1004.943 & 568.1534 & 0.2732032 & 367.8813 & 613.264 & 874.813 & 1247.91 & 2080.28 & 3160045 \\
\hline Oklahoma & Gas & 121.0211 & 97.97206 & 0 & 29.25939 & 58.271 & 94.062 & 151.837 & 302.387 & 24879 \\
\hline
\end{tabular}

Panel 40. Unconditional-2 allocation of undeveloped resources to parcel: gas in oil fields and NGL in gas fields. Mean, standard deviation, minimum, and maximum are computed by applying the geoacc probability from Panel 35 to parameters from Panel 16. Fractiles F95, F75, F50, F25, and F5 are approximated by a lognormal distribution.

\begin{tabular}{|c|c|c|c|c|c|c|c|c|c|}
\hline \multicolumn{9}{|c|}{ UNCONDITIONAL ALLOCATION OF UNDEVELOPED RESOURCES TO PARCEL } & \multirow[t]{3}{*}{ (Panel 41) } \\
\hline & & \multirow{2}{*}{\multicolumn{7}{|c|}{$\begin{array}{c}\text { NGL in Oil Fields (mmbngl) } \\
\text { Oil in Gas Fields (mmbo) }\end{array}$}} & \\
\hline & & & & & & & & & \\
\hline Parcel & Flds I & Mean & S.D. & Min,F100 F95 & F75 & Med,F50 & F25 & F5 & Max,F0 \\
\hline Texas & Oil & 20.09885 & 12.30167 & $\begin{array}{ll}0.002732 & 6.7785585 \\
\end{array}$ & 11.717891 & 17.14276 & 25.07909 & 43.353477 & 74801.34 \\
\hline Oklahoma & Gas & 0 & 0 & 0 \#DIV/0! & \#DIV/O! & \#DIV/O! & \#DIV/0! & \#DIV/0! & 0 \\
\hline
\end{tabular}

Panel 41. Unconditional-2 allocation of undeveloped resources to parcel: NGL in oil fields and oil in gas fields. Mean, standard deviation, minimum, and maximum are computed by applying the geoacc probability from Panel 35 to parameters from Panel 17. Fractiles F95, F75, F50, F25, and F5 are approximated by a lognormal distribution. Cells with "\#DIV/0!" are not calculated because the distribution is not lognormal.

\begin{tabular}{|l|l|l|r|r|r|r|r|r|r|}
\hline \multicolumn{8}{|c|}{ UNCONDITIONAL ALLOCATION OF UNDEVELOPED RESOURCES TO PARCEL } \\
Total Resources in Oil Fields (mmbo \& mmboe \& mmbngl) \\
\hline \\
\hline
\end{tabular}

Panel 42. Unconditional-2 allocation of undeveloped resources to parcel: total resources in oil fields and total resources in gas fields. Mean, standard deviation, minimum, and maximum are computed by applying the geoacc probability from Panel 35 to parameters from Panel 18. Fractiles F95, F75, F50, F25, and F5 are approximated by a lognormal distribution. 


\begin{tabular}{|c|c|c|c|c|c|c|c|c|c|c|}
\hline \multicolumn{10}{|c|}{ UNCONDITIONAL ALLOCATION OF UNDEVELOPED RESOURCES TO OFFSHORE } & \multirow[t]{2}{*}{ (Panel 43) } \\
\hline & & \multicolumn{8}{|c|}{ Oil in Oil Fields (mmbo) } & \\
\hline & & \multicolumn{9}{|c|}{ Gas in Gas Fields (bcfg) } \\
\hline Parcel & Flds & Mean & S.D. & & Min,F100 F95 & F75 & Med,F50 & F25 & F5 & Max,F0 \\
\hline Texas & Oil & & 0 & 0 & 0 \#DIV/0! & \#DIV/0! & \#DIV/O! & \#DIV/O! & \#DIV/0! & 0 \\
\hline Oklahoma & Gas & & 0 & 0 & 0 \#DIV/O! & \#DIV/O! & \#DIV/O! & \#DIV/O! & \#DIV/O! & 0 \\
\hline
\end{tabular}

Panel 43. Unconditional-2 allocation of undeveloped resources to offshore portion of parcel: oil in oil fields and gas in gas fields. Mean, standard deviation, minimum, and maximum are computed by applying the geoacc probability from Panel 35 to parameters from Panel 19. Fractiles F95, F75, F50, F25, and F5 are approximated by a lognormal distribution. Cells with "\#DIV/0!" are not calculated because the distribution is not lognormal.

\begin{tabular}{|c|c|c|c|c|c|c|c|c|c|c|c|}
\hline \multicolumn{11}{|c|}{ UNCONDITIONAL ALLOCATION OF UNDEVELOPED RESOURCES TO OFFSHORE } & \multirow[t]{2}{*}{ (Panel 44) } \\
\hline & & \multirow{2}{*}{\multicolumn{10}{|c|}{$\begin{array}{c}\text { Gas in Oil Fields (bcfg) } \\
\text { NGL in Gas Fields (mmbngl) }\end{array}$}} \\
\hline & & & & & & & & & & & \\
\hline Parcel & Flds & s Mean & S.D. & & Min,F100 & F95 & F75 & Med,F50 & $\mathrm{F} 25$ & F5 & Max,F0 \\
\hline Texas & Oil & & 0 & 0 & 0 & \#DIV/O! & \#DIV/0! & \#DIV/0! & \#DIV/0! & \#DIV/0! & 0 \\
\hline Oklahoma & Gas & & 0 & 0 & 0 & \#DIV/O! & \#DIV/O! & \#DIV/O! & \#DIV/O! & \#DIV/O! & 0 \\
\hline
\end{tabular}

Panel 44. Unconditional-2 allocation of undeveloped resources to offshore portion of parcel: gas in oil fields and NGL in gas fields. Mean, standard deviation, minimum, and maximum are computed by applying the geoacc probability from Panel 35 to parameters from Panel 20. Fractiles F95, F75, F50, F25, and F5 are approximated by a lognormal distribution. Cells with "\#DIV/0!" are not calculated because the distribution is not lognormal.

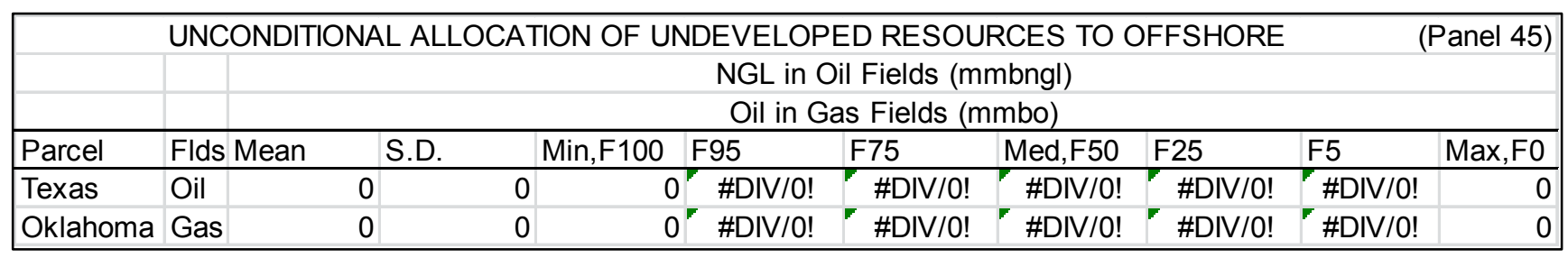

Panel 45. Unconditional-2 allocation of undeveloped resources to offshore portion of parcel: NGL in oil fields and oil in gas fields. Mean, standard deviation, minimum, and maximum are computed by applying the geoacc probability from Panel 35 to parameters from Panel 21. Fractiles F95, F75, F50, F25, and F5 are approximated by a lognormal distribution. Cells with "\#DIV/0!" are not calculated because the distribution is not lognormal. 


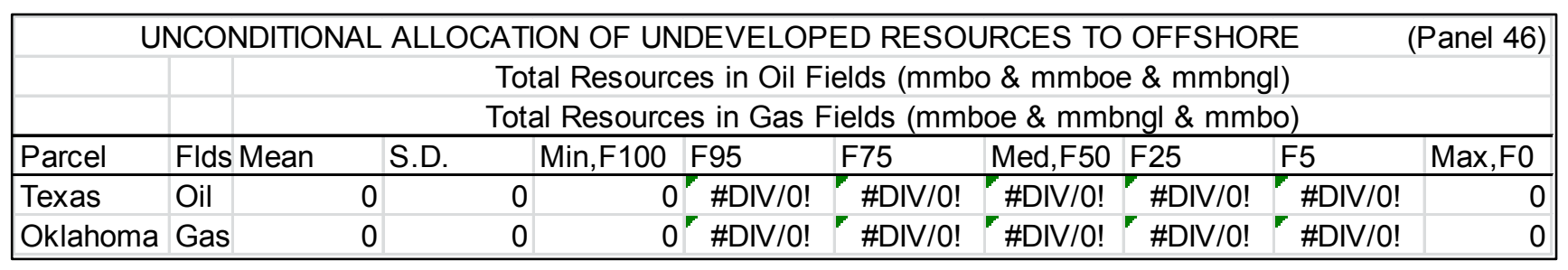

Panel 46. Unconditional-2 allocation of undeveloped resources to offshore portion of parcel: total resources in oil fields and total resources in gas fields. Mean, standard deviation, minimum, and maximum are computed by applying the geoacc probability from Panel 35 to parameters from Panel 22. Fractiles F95, F75, F50, F25, and F5 are approximated by a lognormal distribution. Cells with "\#DIV/0!" are not calculated because the distribution is not lognormal.

\begin{tabular}{|c|c|c|c|c|c|c|c|c|c|c|c|c|c|}
\hline & & & & & & & & & & & & \multicolumn{2}{|c|}{ (Panel 47) } \\
\hline & & & & & \multirow{2}{*}{\multicolumn{3}{|c|}{$\begin{array}{c}\text { Untested } \\
\text { Percentage (\%) }\end{array}$}} & \multicolumn{4}{|c|}{ Potential/Untested } & & \\
\hline & & \multicolumn{3}{|c|}{ Assessment-Unit Area (acres) } & & & & \multicolumn{3}{|c|}{ Percentage (\%) } & Area $\mathrm{P}$ & Per Cell & (acres) \\
\hline No. & Flds & Minimum & Mode & Maximum & Min & Mod & Max & Min & Mod & Max & Min & Mod & Max \\
\hline 50490170 & Oil & 14827000 & 16474000 & 18121000 & 100 & 100 & 100 & 0.5 & 9 & 40 & 80 & 128 & 320 \\
\hline 50620261 & Gas & 5800000 & 6100000 & 6400000 & 96 & 97 & 98 & 10 & 35 & 70 & 60 & 120 & 320 \\
\hline
\end{tabular}

Panel 47. Input data for number of potential cells: assessment-unit area, untested percentage of assessment-unit area, potential percentage of untested area, and area per cell -minimum, mode, and maximum.

\begin{tabular}{|c|c|c|c|c|c|c|c|c|}
\hline & & & & & & & & (Panel 48) \\
\hline & & & & & & & & \\
\hline & & \multicolumn{7}{|c|}{ Assessment-Unit Area (acres) -- Triangular Distribution } \\
\hline No. & Flds & Min,F100 & Med,F50 & Max,F0 & Midpoint & Mode & Mean & S.D. \\
\hline 50490170 & Oil & 14827000 & 16474000 & 18121000 & 16474000 & 16474000 & 16474000 & 672384.9 \\
\hline 50620261 & Gas & 5800000 & 6100000 & 6400000 & 6100000 & 6100000 & 6100000 & 122474.5 \\
\hline
\end{tabular}

Panel 48. Assessment-unit area: triangular distribution. Midpoint, median, mean, and standard deviation are computed. 


\begin{tabular}{|l|l|l|l|r|r|r|r|r|r|}
\hline & & & & & & & (Panel 49) \\
\hline & & & & & & & \\
\hline No. & Flds & & & & & \\
\hline 50490170 & Oil & 100 & 100 & & 100 & 100 & 100 & 100 & 0 \\
\hline 50620261 & Gas & 96 & 97 & 98 & 97 & 97 & 97 & 0.408248 \\
\hline
\end{tabular}

Panel 49. Untested percentage of assessment-unit area: triangular distribution. Midpoint, median, mean, and standard deviation are computed.

\begin{tabular}{|c|c|c|c|c|c|c|c|c|}
\hline & & & & & & & & (Panel 50) \\
\hline & & & & & & & & \\
\hline & & \multicolumn{7}{|c|}{ Potential/Untested Percentage (\%) -- Triangular Distribution } \\
\hline No. & Flds & Min,F100 & Med,F50 & Max,F0 & Midpoint & Mode & Mean & S.D. \\
\hline 50490170 & Oil & 0.5 & 15.25631 & 40 & 20.25 & 9 & 16.5 & 8.487736 \\
\hline 50620261 & Gas & 10 & 37.5963 & 70 & 40 & 35 & 38.33333 & 12.30402 \\
\hline
\end{tabular}

Panel 50. Potential percentage of untested area: triangular distribution. Midpoint, median, mean, and standard deviation are computed.

\begin{tabular}{|c|c|c|c|c|c|c|c|c|}
\hline & & & & & & & & (Panel 51) \\
\hline & & & & & & & & \\
\hline & & \multicolumn{7}{|c|}{ Area Per Cell (acres) -- Triangular Distribution } \\
\hline No. & Flds & Min,F100 & Med,F50 & Max,F0 & Midpoint & Mode & Mean & S.D. \\
\hline 50490170 & Oil & 80 & 168.2107 & 320 & 200 & 128 & 176 & 51.84593 \\
\hline 50620261 & Gas & 60 & 158.7548 & 320 & 190 & 120 & 166.6667 & 55.57777 \\
\hline
\end{tabular}

Panel 51. Area per cell: triangular distribution. Midpoint, median, mean, and standard deviation are computed. 


\begin{tabular}{|c|c|c|c|c|c|c|c|c|c|c|}
\hline & & & & & & & & & & (Panel 52) \\
\hline & & & & & & & & & & \\
\hline & & \multicolumn{9}{|c|}{ Potential Untested Percentage (\%) } \\
\hline No. & Flds & Mean & S.D. & Min,F100 & F95 & F75 & Med,F50 & F25 & F5 & Max,F0 \\
\hline 50490170 & Oil & 16.5 & 8.487736 & 0.5 & 6.612732 & 10.58213 & 14.67252 & 20.344 & 32.5558 & 40 \\
\hline 50620261 & Gas & 37.18333 & 11.93603 & 9.6 & 21.15147 & 28.66267 & 35.40396 & 43.73077 & 59.26021 & 68.6 \\
\hline
\end{tabular}

Panel 52. Potential percentage of assessment-unit area. Mean, standard deviation, minimum, and maximum are computed by combining parameters from Panels 48 and 49. Fractiles F95, F75, F50, F25, and F5 are approximated by a lognormal distribution.

\begin{tabular}{|c|c|c|c|c|c|c|c|c|c|c|}
\hline & & & & & & & & & & (Panel 53) \\
\hline & & & & & & & & & & \\
\hline & & \multicolumn{9}{|c|}{ Potential Untested Area (acres) } \\
\hline No. & Flds & Mean & S.D. & Min,F100 & F95 & F75 & Med,F50 & F25 & F5 & Max,F0 \\
\hline 50490170 & Oil & 2718210 & 1403825 & 74135 & 1085410 & 1739836 & 2415140 & 3352558 & 5373915 & 7248400 \\
\hline 50620261 & Gas & 2268183 & 729667.1 & 556800 & 1288617 & 1747313 & 2159207 & 2668196 & 3617968 & 4390400 \\
\hline
\end{tabular}

Panel 53. Potential untested area of assessment unit. Mean, standard deviation, minimum, and maximum are computed by combining parameters from Panels 48 and 49. Fractiles F95, F75, F50, F25, and F5 are approximated by a lognormal distribution.

\begin{tabular}{|c|c|c|c|c|c|c|c|c|c|c|}
\hline & & & & & & & & & & (Panel 54) \\
\hline & & & & & & & & & & \\
\hline & & \multicolumn{9}{|c|}{ Number of Potential Untested Cells } \\
\hline No. & Flds & Mean & S.D. & Min,F100 & F95 & F75 & Med,F50 & F25 & $\mathrm{F} 5$ & Max,F0 \\
\hline 50490170 & Oil & 15444.38 & 7976.192 & 232 & 6167 & 9885 & 13722 & 19049 & 30533 & 90605 \\
\hline 50620261 & Gas & 13609.1 & 4377.83 & 1740 & 7732 & 10484 & 12955 & 16009 & 21707 & 73173 \\
\hline
\end{tabular}

Panel 54. Number of potential untested cells. Mean, standard deviation, minimum, and maximum are computed by combining parameters from Panels 50 and 51. Fractiles F95, F75, F50, F25, and F5 are approximated by a lognormal distribution. 